Review

\title{
Does Bisphenol A Confer Risk of Neurodevelopmental Disorders? What We Have Learned from Developmental Neurotoxicity Studies in Animal Models
}

\author{
Chloe Welch ${ }^{1}$ and Kimberly Mulligan ${ }^{2, *}$ \\ 1 Division of Biological Sciences, University of California, San Diego, 9500 Gilman Drive, \\ La Jolla, CA 92093, USA; cwelch@ucsd.edu \\ 2 Department of Biological Sciences, California State University, Sacramento, 6000 J Street, \\ Sacramento, CA 95819, USA \\ * Correspondence: kimberly.mulligan@csus.edu
}

check for updates

Citation: Welch, C.; Mulligan, K. Does Bisphenol A Confer Risk of Neurodevelopmental Disorders? What We Have Learned from Developmental Neurotoxicity Studies in Animal Models. Int. J. Mol. Sci. 2022, 23, 2894. https://doi.org/ $10.3390 /$ ijms 23052894

Academic Editors: Nicolas Chevalier and Charlotte Hinault-Boyer

Received: 29 January 2022

Accepted: 5 March 2022

Published: 7 March 2022

Publisher's Note: MDPI stays neutral with regard to jurisdictional claims in published maps and institutional affiliations.

Copyright: (c) 2022 by the authors. Licensee MDPI, Basel, Switzerland. This article is an open access article distributed under the terms and conditions of the Creative Commons Attribution (CC BY) license (https:// creativecommons.org/licenses/by/ $4.0 /)$.

\begin{abstract}
Substantial evidence indicates that bisphenol A (BPA), a ubiquitous environmental chemical used in the synthesis of polycarbonate plastics and epoxy resins, can impair brain development. Clinical and epidemiological studies exploring potential connections between BPA and neurodevelopmental disorders in humans have repeatedly identified correlations between early BPA exposure and developmental disorders, such as attention deficit/hyperactivity disorder and autism spectrum disorder. Investigations using invertebrate and vertebrate animal models have revealed that developmental exposure to BPA can impair multiple aspects of neuronal development, including neural stem cell proliferation and differentiation, synapse formation, and synaptic plasticity-neuronal phenotypes that are thought to underpin the fundamental changes in behavior-associated neurodevelopmental disorders. Consistent with neuronal phenotypes caused by BPA, behavioral analyses of BPA-treated animals have shown significant impacts on behavioral endophenotypes related to neurodevelopmental disorders, including altered locomotor activity, learning and memory deficits, and anxiety-like behavior. To contextualize the correlations between BPA and neurodevelopmental disorders in humans, this review summarizes the current literature on the developmental neurotoxicity of BPA in laboratory animals with an emphasis on neuronal phenotypes, molecular mechanisms, and behavioral outcomes. The collective works described here predominantly support the notion that gestational exposure to BPA should be regarded as a risk factor for neurodevelopmental disorders.
\end{abstract}

Keywords: bisphenol A; endocrine disruptors; neurodevelopmental disorder; neural stem cell development; synaptogenesis; synaptic plasticity; behavior

\section{Introduction}

Bisphenol A (BPA, 2,2-bis (4'-hydroxyphenyl) propane), a ubiquitous chemical used in the synthesis of polycarbonate plastic and epoxy resins, is taking shape as a risk factor for neurodevelopmental disorders (NDDs). NDDs refer to a heterogeneous group of nervous system disorders caused by changes in brain development, including autism spectrum disorder (ASD), attention deficit/hyperactivity disorder (ADHD), intellectual disability (ID), learning disabilities, cerebral palsy, seizure disorders, and impairments in vision and hearing. Analysis of the prevalence of developmental disabilities in the United States (U.S.) between 2009 and 2017 indicated that $16.93 \%$ of children were diagnosed with an NDD [1] Studies have also found that the prevalence of NDDs has increased significantly over the past several decades-most notably, the incidence ASD has increased by almost 300 percent in the last 20 years $[2,3]$.

NDDs have complex etiologies and can result from both genetic susceptibilities and environmental factors [4,5]. Given the increasing prevalence of BPA in our environment [6], along with numerous studies showing an association between human BPA exposure and 
NDDs [7-9], BPA has garnered increasing attention over the past fifteen years for its ability to disrupt brain development. The aim of this review is to summarize studies that have delineated neurodevelopmental consequences of early (prenatal or perinatal) BPA exposure in animal models in an effort to illuminate the mechanisms by which it may impede human brain development.

BPA is categorized as an endocrine disrupting chemical (EDC) due to its ability to bind endogenous hormone receptors and cause adverse effects. Structurally similar to estradiol, BPA is most well-known for its ability to agonize and antagonize estrogen receptor (ER) subtypes and antagonize androgen receptors [10,11]. BPA also elicits non-estrogenic/nonandrogenic impacts on development by binding other receptors, including the thyroid hormone receptor [12,13], glucocorticoid receptor [14-16], the G protein-coupled receptor, GPR30 [17] and Peroxisome Proliferator-Activated Receptor $\gamma(\operatorname{PPAR} \gamma)[18,19]$. The ability of BPA to influence hormonal signaling was first documented in the 1930s [20,21]. Despite awareness of its endocrine disrupting capability, BPA was adapted for use in the synthesis of polycarbonate plastics in the 1950s and quickly became one of the most prevalent synthetic compounds in the world [6,22]. An estimated 7.7 million metric tons of BPA were generated worldwide in 2015, and production is expected to rise to 10.6 million metric tons in 2022 [6].

BPA enters the body via ingestion, dermal absorption, and inhalation, with ingestion being the most common route of exposure [23-25]. A wide array of products used in everyday life contain BPA, including plastic containers, thermal papers, food cans, and beverage cans [26-28]. Residual BPA can leach from these products due to incomplete polymerization during production or from depolymerization when exposed to high temperatures or extreme $\mathrm{pH}$ conditions, which speed up the hydrolysis of ester bonds that link BPA monomers [6].

Due to concerns surrounding the endocrine disrupting capabilities of BPA, the European Union banned its use in all infant products beginning in 2011, and the U.S. Food and Drug Administration followed suit in 2012. However, BPA remains pervasive in our environments; of greatest concern, pregnant women are still persistently exposed to BPA in a variety of ways. The lipophilic structure of BPA allows it to readily cross cell membranes, as well as both placental and blood-brain barriers [29-31], enabling its ability to potentially affect the neurodevelopmental program of a growing embryo or fetus.

Despite vast evidence that BPA should be more tightly regulated, establishing safe exposure levels is complicated as is evidenced by the varied reference doses in different countries. For example, the current reference dose set by the Environmental Protection Agency in the U.S. is $50 \mathrm{mg} / \mathrm{kg} /$ day [32], the set tolerable dose intake (TDI) in Canada is $25 \mathrm{mg} / \mathrm{kg} /$ day [33], while the European Food Safety Authority (EFSA) set their TDI at $4 \mathrm{mg} / \mathrm{kg} /$ day [34].

The reference doses of BPA may be reasonable limits for adults, but the research summarized in this review and others suggest that doses in the $\mathrm{ng} / \mathrm{kg} /$ day range may have deleterious impacts on the developing brains of laboratory animals [35]. In adult humans, BPA does not bioaccumulate and is metabolized and excreted within $48 \mathrm{~h}$; however, given its environmental prevalence, many individuals experience chronic exposure. In addition, while BPA exposure levels are generally low in adults, averaging $0.043 \mathrm{mg} / \mathrm{kg} /$ day in Canada and $0.073 \mathrm{mg} / \mathrm{kg} /$ day in the U.S. [32], fetal, infant, and child exposure levels are much higher. In Canada, infants were found to consume up to $1.32 \mathrm{mg} / \mathrm{kg} /$ day [32], and in Europe the estimates for child BPA exposure were as high as $13 \mathrm{mg} / \mathrm{kg} /$ day $[36,37]$. Of particular concern regarding NDD pathophysiology, analysis of free versus conjugated BPA in human fetal samples demonstrated a reduced capacity of the fetus to metabolize BPA [38]. In this study, measurement of BPA in fetal liver samples indicated a geometric mean of $2.26 \mathrm{ng} / \mathrm{g} \mathrm{BPA} /$ wet weight, with individual samples measuring as high as $50 \mathrm{ng} / \mathrm{g}$ (or $50 \mathrm{mg} / \mathrm{kg}$ ) [38] —higher than the daily recommended exposure limitations for BPA in some countries.

Like many other EDCs, BPA can elicit non-monotonic dose responses [39,40], which yield U-shaped dose response curves instead of linear dose response curves. BPA may also 
cause distinct responses depending on the developmental time point of exposure. Thus, depending on the dose administered and duration of exposure, a higher dose of BPA can elicit a milder phenotype than a lower dose $[22,40,41]$, meaning that, when a particular dose of BPA fails to elicit a negative health impact, it cannot be assumed that all lower doses are safe.

Consistent with the brain being a commonly reported target of EDCs [42], early BPA exposure is associated with behavioral impairment and NDDs in children [7-9]. Longitudinal studies that measured maternal BPA exposure levels during pregnancy and subsequently examined the children identified positive correlations between BPA and ADHD-related symptoms [43], learning deficits [44,45], externalizing behaviors [46], and anxiety and depression [47]. Cross-sectional and case-controlled studies examining concurrent BPA exposure levels found positive correlations between BPA exposure and both ASD [48,49] and ADHD [50,51]. A recent longitudinal study went a step further by examining both behavior and diffusion magnetic resonance images of children's brains. In this study, analysis of 98 mother-child pairs revealed higher maternal urinary BPA concentrations at mid-gestation correlated with both internalizing problems and altered white matter microstructure when their children reached preschool age [52].

While studies examining the impact of BPA on brain structure in humans are rare, numerous studies have investigated the developmental neurotoxicity of BPA by examining the brains of animal models or cultured neurons. Here, we describe recent studies that have shed light on some of the cellular and molecular mechanisms by which BPA interferes with brain development to cause behavioral endophenotypes common to NDDs.

\section{Neural Stem Cell Proliferation and Differentiation Are Affected by BPA}

One of the first critical cellular processes of neurodevelopment is neurogenesis, a tightly regulated process that involves the migration, proliferation, and differentiation of neural precursor cells into functional units of circuitry [53,54]. During this process, neural stem cells (NSCs) and neural progenitor cells (NPCs) transition into neurons and glia [55]. Neurogenesis begins during embryonic brain development and continues in localized areas of the adult mammalian brain, including the subventricular zone and the dentate gyrus in the hippocampus $[55,56]$.

Disruptions and abnormalities in neurogenesis have been implicated in various NDDs and neuropsychiatric illnesses $[57,58]$. Neurogenesis can be investigated at the cellular and molecular levels by evaluating proliferation rates and expression patterns of key genes and proteins during differentiation of NSCs/NPCs. Proper proliferation and differentiation of precursor cell types relies heavily on intrinsic factors, such as mitogens, small molecules, and cell signaling pathways, but are also influenced by extrinsic factors, such as environmental chemical exposures [59-66]. Indeed, maternal exposure to BPA has been studied in various model organisms and has been shown to influence the proliferative capacity of NSCs and neuronal differentiation (Table 1) [54,67-74].

As the developing nervous system is highly complex, in vitro assays using cell-based models of neurogenesis have become a valuable tool to study NSC/NPC proliferation and differentiation [75]. Following exposure to BPA, disruptions in rates of cell proliferation and neuronal differentiation have been observed in NSCs/NPCs and neuron cultures derived from the rat hippocampus [54,71], embryonic and fetal brain [68,69], the mouse brain [72], human umbilical cord blood [70], and human brain-derived cell lines [73,74] in response to various dosing regimens of BPA. In NSCs derived from the rat hippocampus and in human brain-derived cells, BPA was found to cause a significant decrease in BrdUpositive [71] and $\beta$-III tubulin-positive cells [71,74], which are biomarkers of neuronal proliferation and differentiation, respectively. In cells derived from rat embryonic and fetal brains, BPA was also found to have adverse effects on the processes of neuronal and glial maturation $[68,69]$. Upon exposure to concentrations of BPA ranging from 0.05 to $100 \mu \mathrm{M}$, decreases in neuron and oligodendrocyte maturation were observed as was an increase in astrocyte differentiation [68]. 
BPA exposure has also been found to affect regions of the brain important for neuronal and glial homeostasis. Rats chronically exposed to $100 \mu \mathrm{g} / \mathrm{L} \mathrm{BPA}$ during prenatal development and postnatal weaning were found to have significantly enlarged lateral ventricles [76]. Lateral ventricle enlargement was speculated as being caused by a BPAinduced increase in cerebrospinal fluid (CSF) pressure and circulation [76], which could directly affect developing neurons and glia given the critical role CSF plays in maintaining brain homeostasis.

Investigators have also identified multiple molecular mechanisms by which BPA exposure disrupts the differentiation of cultured NSCs/NPCs. One such mechanism is the BPA-mediated disruption of the Wnt pathway, a signaling pathway that influences NSC/NPC development and a known contributor to the pathophysiology of NDDs and neuropsychiatric disorders $[77,78]$. BPA treatment was found to significantly reduce the activity of the Wnt pathway, demonstrated by altered expression of Wnt pathway genes, as well as reduced cellular $\beta$-catenin levels, reduced phosphorylation of GSK-3 $\beta$ (Glycogen Synthase Kinase 3 Beta), and reduced $\beta$-catenin translocation to the nucleus [54,71]. Transcription factors critical for neuronal differentiation are also impacted by BPA treatment. One study using cells derived from human umbilical cord blood showed decreased mRNA and protein levels of Sox1, Pax6, and Ngn1, and increased levels of Oct4 and Gdf3 [70]. Sox1, Pax6, and Ngn1 are actively expressed during neuronal differentiation, while expression of multipotential markers, such as Oct4 and Gdf3, is repressed [70,79]. Another analysis using human brain-derived NSC found that concentrations of BPA as low as $1 \mu \mathrm{M}$ resulted in a decrease in GFAP (Glial fibrillary acidic protein) and MAP2 (Microtubule associated protein 2) protein expression (markers of neuronal differentiation) as well as an increase in Nestin and Sox2 expression (markers of NSC maintenance) [73].

Although not as extensive as in vitro studies, there have also been studies investigating the impact of BPA on NSC/NPC proliferation and differentiation in vivo. For example, Tiwari et al. found that perinatal exposure in rats to 40 and $400 \mathrm{ug} / \mathrm{kg} /$ day caused a significant reduction in BrdU-positive NPCs in the hippocampus and subventricular zone (SVZ) of offspring [54]. Further, immunofluorescent labeling of lineage-specific markers showed BPA exposure caused a significant increase in GFAP-positive cells (a glial marker) and a concomitant decrease in nestin, b-tubulin, neuroD1, and doublecortin (DCX) expression (neuronal markers) [54]. This data suggests that early BPA exposure can increase glial differentiation and decrease neuronal differentiation, therein, disrupting the ratio of glia to neurons in the rat hippocampus. BPA was also shown to cause premature neurogenesis in the hypothalamus of zebrafish brains at concentrations as low as $0.0068 \mu \mathrm{M}$ [67]. Another study using fruit flies demonstrated that embryonic and larval exposure to $1 \mathrm{mM}$ BPA caused a reduction in the number of mitotically active cells in the larval brain [41].

The ability of NSCs/NPCs to proliferate and differentiate at appropriate rates is critical for neurogenesis and brain function. Both in vitro studies with cells derived from mammalian models and in vivo studies using vertebrate and invertebrate models have provided evidence that BPA exposure disrupts NSC/NPC proliferation. The delineated mechanisms involve BPA-mediated impairment of signaling pathways and gene expression critical for NSC/NPC development. Given the key role neurogenesis plays in brain development, this data demonstrates that BPA may confer a risk of NDDs by interrupting NSC/NPC development.

Table 1. Summary of studies on BPA-associated impacts on neural stem cell (NSC) development.

\begin{tabular}{lllll}
\hline $\begin{array}{l}\text { Neural Structure/ } \\
\text { Cell Type }\end{array}$ & Organism & Phenotype & Concentration & Reference \\
\hline $\begin{array}{l}\text { Central brain } \\
\text { (larval) }\end{array}$ & $\begin{array}{l}\text { Drosophila } \\
\text { melanogaster }\end{array}$ & $\begin{array}{l}\text { Reduced proliferation of } \\
\text { neuroblasts }\end{array}$ & $\begin{array}{l}1 \mathrm{mM} \\
\text { (developmental) }\end{array}$ & Nguyen et al., 2021 [41] \\
\hline Hypothalamus & Danio rerio & Premature neurogenesis & $\begin{array}{l}0.0068 \mu \mathrm{M} \\
\text { (developmental) }\end{array}$ & Kinch et al., 2015 [67] \\
\hline
\end{tabular}


Table 1. Cont.

\begin{tabular}{|c|c|c|c|c|}
\hline $\begin{array}{l}\text { Neural Structure/ } \\
\text { Cell Type }\end{array}$ & Organism & Phenotype & Concentration & Reference \\
\hline Neural progenitor cells & Mus musculus & $\begin{array}{l}\text { High concentration } \\
(>100 \mu \mathrm{M}) \text { resulted in } \\
\text { decrease in proliferation }\end{array}$ & $1 \mathrm{nM}-500 \mu \mathrm{M}$ (in vitro) & Kim et al., 2007 [72] \\
\hline Fetal neural stem cells & $\begin{array}{l}\text { Rattus } \\
\text { norvegicus }\end{array}$ & $\begin{array}{l}\text { Increased cell proliferation; } \\
\text { decreased maturation of } \\
\text { oligodendrocytes and } \\
\text { neurons; } \\
\text { increased astrocyte } \\
\text { differentiation and } \\
\text { morphological changes; } \\
\text { reduced arborization by } \\
\text { astrocytes, } \\
\text { oligodendrocytes, and } \\
\text { neurons }\end{array}$ & $\begin{array}{l}0.05 \mu \mathrm{M}, 0.25 \mu \mathrm{M} \\
10 \mu \mathrm{M}, 50 \mu \mathrm{M}, \text { and } \\
100 \mu \mathrm{M} \text { (in vitro) }\end{array}$ & $\begin{array}{l}\text { Gill and } \\
\text { Kumara., } 2021 \text { [68] }\end{array}$ \\
\hline Lateral ventricles & $\begin{array}{l}\text { Rattus } \\
\text { norvegicus }\end{array}$ & $\begin{array}{l}\text { Enlargement of lateral } \\
\text { ventricles }\end{array}$ & $\begin{array}{l}100 \mu \mathrm{g} / \mathrm{L} \text {; equivalent to } \\
10 \mu \mathrm{g} / \mathrm{kg} / \text { day } \\
\text { (perinatal) }\end{array}$ & Santoro et al., 2021 [76] \\
\hline $\begin{array}{l}\text { Primary neuronal } \\
\text { cultures from } \\
\text { embryonic rat brains }\end{array}$ & $\begin{array}{l}\text { Rattus } \\
\text { norvegicus }\end{array}$ & $\begin{array}{l}\text { Reduced maturation of } \\
\text { neural progenitor cells (at } \\
200 \mu \mathrm{M})\end{array}$ & $\begin{array}{l}50,100 \text {, or } 200 \mu \mathrm{M} \\
\text { (in vitro) }\end{array}$ & Cho et al., 2018 [69] \\
\hline $\begin{array}{l}\text { Hippocampus and } \\
\text { lateral ventricle } \\
\text { (in vivo); hippocampal } \\
\text { neural stem cells } \\
\text { (in vitro) }\end{array}$ & $\begin{array}{l}\text { Rattus } \\
\text { norvegicus }\end{array}$ & $\begin{array}{l}\text { Impaired neural stem cell } \\
\text { proliferation and } \\
\text { differentiation (hippocampus } \\
\text { and subventricular zone); } \\
\text { altered expression/protein } \\
\text { levels of neurogenic genes } \\
\text { (hippocampus); reduced Wnt } \\
\text { pathway activity } \\
\text { (hippocampus) }\end{array}$ & $\begin{array}{l}4,40, \text { and } \\
400 \mu \mathrm{g} / \mathrm{kg} / \text { day } \\
\text { (perinatal) }\end{array}$ & Tiwari et al., 2015 [54] \\
\hline $\begin{array}{l}\text { Hippocampus (in vivo) } \\
\text { and hippocampal } \\
\text { neural stem cells } \\
\text { (in vitro) }\end{array}$ & $\begin{array}{l}\text { Rattus } \\
\text { norvegicus }\end{array}$ & $\begin{array}{l}\text { Inhibited } \\
\text { hippocampal-derived neural } \\
\text { stem cell proliferation and } \\
\text { differentiation }\end{array}$ & $\begin{array}{l}40 \mu \mathrm{g} / \mathrm{kg} / \text { day } \\
\text { (perinatal) }\end{array}$ & $\begin{array}{l}\text { Agarwal et al., } \\
2016[71]\end{array}$ \\
\hline Neural stem cells & Homo sapiens & $\begin{array}{l}\text { Promoted cell proliferation } \\
(0.1 \text { and } 1 \mu \mathrm{M}) \text {; inhibited } \\
\text { differentiation }(1 \mu \mathrm{M}) ; \\
\text { reduced GFAP and MAP2 } \\
\text { expression }(1 \mu \mathrm{M}) ; \text { increased } \\
\text { expression of nestin and } \\
\text { Sox2 }(1 \mu \mathrm{M})\end{array}$ & $\begin{array}{l}0.1,1,5 \text {, and } 10 \mu \mathrm{M} \\
\text { (in vitro) }\end{array}$ & Dong et al., 2021 [73] \\
\hline $\begin{array}{l}\text { Fetal brain- } \\
\text { derived neural } \\
\text { progenitor cells }\end{array}$ & Homo sapiens & $\begin{array}{l}\text { Reduced neuronal } \\
\text { differentiation (decreased } \beta \\
\text { III-tubulin mRNA levels and } \\
\beta \text { III-tubulin-positive cells) }\end{array}$ & $\begin{array}{l}10^{-16}, 10^{-13} \text {, and } 10^{-10} \\
M \text { (in vitro) }\end{array}$ & $\begin{array}{l}\text { Fujiwara et al., } \\
2018 \text { [74] }\end{array}$ \\
\hline $\begin{array}{l}\text { Neural stem cells from } \\
\text { umbilical cord blood }\end{array}$ & Homo sapiens & $\begin{array}{l}\text { Reduced NSC proliferation } \\
\text { and differentiation }\end{array}$ & $\begin{array}{l}50 \text { and } 100 \mu \mathrm{mol} / \mathrm{L} \\
\text { (in vitro) }\end{array}$ & Huang et al., 2019 [70] \\
\hline
\end{tabular}

\section{Synapse Formation Is Disrupted by BPA}

The process of synapse formation, or synaptogenesis, occurs when a neuron responds to guidance cues by extending its axon toward a target cell (a neuron, gland, or muscle cell) and forms an adhesion that enables neuronal communication across a synapse. Throughout the central and peripheral nervous systems, synaptogenesis gives rise to the specialized neural networks responsible for receiving and integrating sensory stimuli in order to actuate 
functional responses [80-82]. Thus, the input-output mechanisms of the brain that facilitate appropriate behavioral responses are dependent on successful synapse formation [80-82].

NDDs, which are often behaviorally-defined, can be caused by disruptions in synaptogenesis [80]; therefore, elucidating the impacts of BPA on synapse formation is critical because of the implications for risk of neurodevelopmental impairment. Experimentally, synapse formation can be measured at the cellular and molecular level by evaluating axon growth and guidance [41,83-85], dendrite length and arborization patterns [86-88], and the expression levels of genes and proteins critical for the synaptogenic program [89]. BPA-associated deficits in synapse formation have been examined in the fruit fly $[41,85]$, zebrafish [83,84], rodents [87-89], and embryonic stem cell-derived models from humans (Table 2) [86].

Table 2. Summary of studies that have investigated the impact of BPA on synapse formation.

\begin{tabular}{|c|c|c|c|c|}
\hline $\begin{array}{l}\text { Neural Structure/Cell } \\
\text { Type }\end{array}$ & Organism & Phenotype & Exposure & Reference \\
\hline Mushroom body & $\begin{array}{l}\text { Drosophila } \\
\text { melanogaster }\end{array}$ & $\begin{array}{l}\text { Increased axon midline } \\
\text { crossing (axon guidance } \\
\text { defect) }\end{array}$ & $\begin{array}{l}0.1 \text { and } 1 \mathrm{mM} \\
\text { (developmental) }\end{array}$ & Nguyen et al., 2021 [41] \\
\hline $\begin{array}{l}\text { Neuromuscular } \\
\text { junction (NMJ) }\end{array}$ & $\begin{array}{l}\text { Drosophila } \\
\text { melanogaster }\end{array}$ & Increased axonal branches & $\begin{array}{l}1 \mathrm{mM} \\
\text { (developmental) }\end{array}$ & Welch et al., 2022 [85] \\
\hline Motor neuron & Danio rerio & $\begin{array}{l}\text { Reduced motor axon length } \\
\text { and branching; reduced NMJ } \\
\text { integrity }\end{array}$ & $\begin{array}{l}50 \mu \mathrm{M} \\
\text { (developmental) }\end{array}$ & Morrice et al., 2018 [83] \\
\hline Motor neuron & Danio rerio & $\begin{array}{l}\text { Decreased ventral and dorsal } \\
\text { axons from secondary } \\
\text { motoneurons (specifically at } \\
15 \mu \mathrm{M} \text { ) }\end{array}$ & $\begin{array}{l}\text { 1, 5, and } 15 \mu \mathrm{M} \\
\text { (developmental) }\end{array}$ & Wang et al., 2013 [84] \\
\hline $\begin{array}{l}\text { Neuroblasts } \\
\text { (Neuro-2A cell line) }\end{array}$ & Mus musculus & $\begin{array}{l}\text { Cell shrinkage, rounding, and } \\
\text { reduced number of synapses; } \\
\text { decreased relative protein and } \\
\text { mRNA expression levels of } \\
\text { Dbn, MAP2 and Tau; increased } \\
\text { the relative protein and mRNA } \\
\text { expression levels of SYP }\end{array}$ & $\begin{array}{l}50,100,150 \text {, or } 200 \mu \mathrm{M} \\
\text { (in vitro) }\end{array}$ & Yin et al., 2020 [89] \\
\hline $\begin{array}{l}\text { Hippocampus } \\
\text { (CA1 area) }\end{array}$ & $\begin{array}{l}\text { Mus musculus } \\
\text { (males only) }\end{array}$ & $\begin{array}{l}\text { Inhibited synaptogenesis; } \\
\text { altered synaptic structure }\end{array}$ & $\begin{array}{l}0.04,0.4 \text {, and } \\
4.0 \mathrm{mg} / \mathrm{kg} / \text { day } \\
\text { (perinatal) }\end{array}$ & Xu et al., 2013 [88] \\
\hline $\begin{array}{l}\text { Hippocampal } \\
\text { neurons }\end{array}$ & $\begin{array}{l}\text { Rattus } \\
\text { norvegicus }\end{array}$ & $\begin{array}{l}\text { Increased total length of } \\
\text { dendrites; increased motility } \\
\text { and density of dendritic } \\
\text { filipodia }\end{array}$ & $\begin{array}{l}\text { 1, 10, and } 100 \mathrm{nM} \\
\text { (in vitro) }\end{array}$ & Xu et al., 2014 [87] \\
\hline $\begin{array}{l}\text { Embryonic stem } \\
\text { cell-derived neural } \\
\text { stem cells }\end{array}$ & Homo sapiens & Decreased neurite outgrowth & $\begin{array}{l}\text { 1, } 10 \text {, and } 100 \mathrm{nM} \\
\text { (in vitro) }\end{array}$ & Liang et al., 2020 [86] \\
\hline
\end{tabular}

Early exposure to BPA has been found to dysregulate axon growth and guidance in fruit flies and zebrafish. In the fruit fly, developmental exposure to $0.1,1$, and $2 \mathrm{mM}$ BPA caused axon guidance defects in a midbrain structure called the mushroom body [41], a neural structure critical for learning and memory [90,91]. Axonal branching has also been examined at the larval neuromuscular junction (NMJ) — a relatively accessible and highly specialized synapse between the nerve terminals of motor neurons and larval body wall muscle fibers $[80,92]$. Analysis of the NMJ in fruit fly larvae showed that exposure to $1 \mathrm{mM}$ BPA can increase axonal branching, which corresponded to transcriptomic data indicating that BPA causes the misexpression of genes involved in axogenesis and synapse 
development [85]. In zebrafish, exposure to $15 \mathrm{mM}$ BPA decreased the length of dorsal and ventral axons extending from secondary NMJ motoneurons [84]. A separate study using zebrafish also demonstrated a BPA-mediated inhibition of motor axon growth, this time showing a dose-dependent decrease in motor axon length following exposure to $15-90 \mathrm{mM}$ during embryogenesis [83]. These studies indicate that developmental exposure to BPA can have adverse effects on axon growth and guidance.

BPA-associated impacts on synapse formation have also been measured in mammalian model organisms and cell lines [87-89]. Similar to the reduced axon outgrowth observed in zebrafish [83,84], BPA treatment of human embryonic stem cell-derived NSCs led to a reduction in neurite length [86]. In contrast, analysis of dendritogenesis in cultured rat hippocampal neurons found treatment with 10-100 nM BPA increased the motility and density of dendritic filipodia, as well as dendrite length [87]. Studies focused on synaptic morphology have revealed BPA can also affect synaptogenesis after the presynaptic and postsynaptic membranes come into contact. Analysis of the hippocampus in male mice following perinatal BPA exposure $(0.4-4 \mathrm{mg} / \mathrm{kg} /$ day $)$ revealed altered structural characteristics of synapses, including enlarged synaptic clefts, reduced active zones, thinned postsynaptic densities, and increased synaptic curvature [88]. Cultured mouse neuroblasts (Neuro-2a/N2a cells) exhibited cell shrinkage and a reduced number of synapses upon exposure to BPA ranging from $50 \mu \mathrm{M}$ to $200 \mu \mathrm{M}$ [89]. BPA also caused reduced expression of Dbn (Drebin), MAP2, and Tau, and increased expression of SYP (Synaptophysin) in N2a cells [90]. Dbn and SYP regulate synaptic morphology and MAP2 and Tau are critical for maintaining stability of the neuronal cytoskeleton. Thus, the BPA-induced misexpression of these critical synaptic proteins provides a molecular explanation for its deleterious impacts on synapse formation and synaptic integrity.

Studies using invertebrate and vertebrate models, in addition to cultured cells, provide evidence that BPA exposure can impair synapse formation by disrupting axogenesis, dendritogenesis, and synaptic structural integrity. BPA has been found to impact the expression of genes critical for synapse formation in invertebrate and mammalian systems [86,90], suggesting that BPA interferes with synaptogenesis at least in part through its dysregulation of neurodevelopmental gene expression.

\section{Synaptic Plasticity Is Impaired by BPA}

Synaptic plasticity - the ability of neurons to modify the strength of their connections in an activity-dependent manner-is the foundation of learning and memory, adaptive social, and emotional behavior and is thought to be a common feature of many NDDs [93-97]. Synaptic plasticity can be measured at the cellular level by assessing dendritic spines, small protrusions along the dendritic membrane where synapses form. The density of dendritic spines changes in response to neural activity; long-term potentiation (LTP) increases spine density [98], whereas long-term depression (LTD) reduces spine density [99].

Chemical exposures can disrupt synaptic plasticity by altering the expression or activity of proteins important for either structural changes in dendritic spines or neuronal signaling pathways that contribute to LTP and LTD. Maternal exposure to BPA has been found to affect the synaptic plasticity of offspring in various brain regions by reducing dendritic spine density [100-102], altering LTP and LTD [103,104], and dysregulating the expression of molecular regulators of plasticity (Table 3) [88,101-106].

The impact of BPA on synaptic plasticity in the hippocampus has been extensively investigated because of the key role hippocampal plasticity plays in learning and memory [96]. Reductions in spine density have been observed in the hippocampus of non-human primates [107], rats $[100,101,105,106]$, and mice $[88,108]$ following prenatal or perinatal exposure to BPA at levels ranging from a very low dose $(30 \mu \mathrm{g} / \mathrm{kg} /$ day $)$ up to a high dose (50 mg/kg/day). Analysis of potential molecular causes of reduced hippocampal spine density suggests BPA can downregulate critical synaptic proteins, including presynaptic synapsin I [88,104], postsynaptic density protein 95 (PSD-95) [88,105,106,109], N-methylD-aspartate (NMDA) receptor subunits [88,105,106,110], $\alpha$-amino-3-hydroxy-5-methyl- 
4-isoxazole propionic acid (AMPA) receptor subunits [105,106], and activity-regulated cytoskeleton-associated protein (Arc), as well as reduced PKC/ERK/CREB signaling [105]. While most of these studies exclusively used male animals, two studies that included both sexes reported different impacts in females and males (males were found to have a more robust decrease in spines) $[100,105]$, one study found BPA-associated effects on plasticity were mediated by ER-a [105], while another study suggested plasticity phenotypes were sex-independent because BPA-associated impacts were indistinguishable in male and female brains [101]. Although there remains some debate about estrogen signaling being involved in BPA-mediated consequences in the central nervous system, all of the referenced studies found that exposure to BPA during development reduced plasticity in the hippocampus, therein, supporting the notion that maternal BPA exposure can cause learning and memory deficits in offspring.

BPA-associated changes in synaptic plasticity have also been identified in the primary visual cortex [102], basal ganglia [104], and basolateral amygdala (BLA) [103] of rats. In the primary visual cortex, reductions in spine density were observed in response to low BPA exposure levels ( $1 \mathrm{mg} / \mathrm{kg} /$ day) [102]. In this case, the reduced spine density was connected to diminished expression of the proinflammatory cytokine, interleukin $1 \beta$ (IL-1 $\beta$ ) [102], which plays a role in LTP [111]. In the basal ganglia, low dose BPA $(20 \mu \mathrm{g} / \mathrm{kg} /$ day $)$ caused deficits in the development of LTP and LTD at the dorsolateral striatum via enhancement of dopamine receptor (D1R) activity, a disruption suggested by the authors to diminish control of motor behaviors [104]; though, it is worth noting the basal ganglia is also critical for non-motor functions, such as emotion and executive function [112]. In the BLA, low dose BPA exposure also caused increased dopaminergic signaling, which triggered elevated LTP in the cortical-BLA pathway [103], neuronal excitability thought to underpin hyperactivity and attention deficits.

Although this review does not focus on adult exposure, numerous studies have found postnatal BPA treatment also has deleterious impacts on synaptic plasticity-typically in the form of reduced dendritic spine density-in the prefrontal cortex and hippocampus of nonhuman primates [113,114], rats [115-119], and mice [120]. The ability of BPA to consistently impair synaptic plasticity in a variety of brain structures critical for cognition and behavior in mammalian models, including non-human primates, rats, and mice, provides compelling evidence that BPA is a risk factor for NDDs in humans, given that aberrant neuroplasticity is a hallmark of these disorders.

Table 3. Summary of studies that have investigated the impact of BPA on synaptic plasticity.

\begin{tabular}{|c|c|c|c|c|}
\hline Brain Region & Organism & Phenotype & Exposure & Reference \\
\hline \multirow{4}{*}{ Hippocampus } & $\begin{array}{l}\text { Mus musculus } \\
\text { (males only) }\end{array}$ & $\begin{array}{l}\text { Downregulated expression of } \\
\text { PSD95 and synaptophysin; } \\
\text { upregulated gephyrin } \\
\text { (inhibitory); reduced excitatory } \\
\text { to inhibitory protein ratio }\end{array}$ & $\begin{array}{c}50 \mu \mathrm{g} / \mathrm{kg} / \text { day } \\
\text { (perinatal) }\end{array}$ & $\begin{array}{c}\text { Kumar and Thakur, } \\
2017 \text { [109] }\end{array}$ \\
\hline & $\begin{array}{l}\text { Mus musculus } \\
\text { (males only) }\end{array}$ & Reduced spine density & $\begin{array}{c}40 \text { or } 400 \mu \mathrm{g} / \mathrm{kg} / \text { day } \\
\text { (prenatal) }\end{array}$ & $\begin{array}{l}\text { Kimura et al., } \\
2016 \text { [108] }\end{array}$ \\
\hline & $\begin{array}{l}\text { Mus musculus } \\
\text { (males only) }\end{array}$ & $\begin{array}{l}\text { Reduced synapsin I, PSD-95, } \\
\text { NMDA receptor subunit NR1, } \\
\text { AMPA receptor subunit GluR1 }\end{array}$ & $\begin{array}{c}0.04,0.4, \text { or } \\
4.0 \mathrm{mg} / \mathrm{kg} / \text { day } \\
\text { (perinatal) }\end{array}$ & Xu et al., 2013 [88] \\
\hline & $\begin{array}{l}\text { Mus musculus } \\
\text { (males only) }\end{array}$ & $\begin{array}{l}\text { Downregulated NMDA } \\
\text { receptor subunits NR1, NR2A, } \\
\text { and } 2 B\end{array}$ & $\begin{array}{c}50,5,0.5, \text { or } \\
0.05 \mathrm{mg} / \mathrm{kg} / \text { day } \\
\quad \text { (perinatal) }\end{array}$ & Xu et al., 2010 [110] \\
\hline
\end{tabular}


Table 3. Cont.

\begin{tabular}{|c|c|c|c|c|}
\hline Brain Region & Organism & Phenotype & Exposure & Reference \\
\hline & Rattus norvegicus & $\begin{array}{l}\text { Reduced spine density in } \\
\text { males; increased spine density } \\
\text { in females at estrus, but } \\
\text { reduced spine density at } \\
\text { proestrus }\end{array}$ & $\begin{array}{l}30 \mathrm{ug} / \mathrm{kg} / \text { day } \\
\text { (perinatal) }\end{array}$ & $\begin{array}{l}\text { Kawato et al., } \\
2021[100]\end{array}$ \\
\hline & Rattus norvegicus & $\begin{array}{l}\text { Downregulated expression of } \\
p \text {-NR2B, NR2B, } p \text {-GluA1, } \\
\text { GluA1, PSD-95, synapsin I, } \\
\text { PKC, } p \text {-ERK and } p \text {-CREB in } \\
\text { males and females (greater } \\
\text { reduction in males) }\end{array}$ & $\begin{array}{c}1 \text { and } 10 \mu \mathrm{g} / \mathrm{mL} \text {, } \\
\text { equivalent to } 0.14 \text { or } \\
1.4 \mathrm{mg} / \mathrm{kg} / \text { day } \\
\text { (perinatal) }\end{array}$ & Wu et al., 2020 [105] \\
\hline & Rattus norvegicus & $\begin{array}{l}\text { Reduced spine density; } \\
\text { increased mIPSC amplitude; } \\
\text { reduced Arc } \\
\text { (activity-regulated } \\
\text { cytoskeleton-associated } \\
\text { protein) expression }\end{array}$ & $\begin{array}{c}0.15-7.5 \mathrm{mg} / \mathrm{kg} / \text { day } \\
\text { (prenatal and postnatal, } \\
\text { through PND 87) }\end{array}$ & Liu et al., 2016 [101] \\
\hline & $\begin{array}{l}\text { Rattus norvegicus } \\
\text { (males only) }\end{array}$ & $\begin{array}{l}\text { Reduced expressions of } \\
\text { synaptophysin, PSD-95, } \\
\text { spinophilin, GluR1 and } \\
\text { NMDAR1 }\end{array}$ & $\begin{array}{c}0.05,0.5,5, \text { or } \\
50 \mathrm{mg} / \mathrm{kg} / \text { day } \\
\text { (perinatal) }\end{array}$ & Wang et al., 2014 [106] \\
\hline & $\begin{array}{l}\text { Macaca mulatta } \\
\text { (females only) }\end{array}$ & $\begin{array}{l}\text { Reduced spine synapses in } \\
\text { CA1, but not PFC }\end{array}$ & $\begin{array}{l}125 \mathrm{mg} \text { delivered } \\
\text { subcutaneously to } \\
\text { pregnant females or } \\
50 \text { days (resulted in } \\
\text { mean serum level of } \\
0.91 \pm 0.13 \mathrm{ng} / \mathrm{mL} \text { ) }\end{array}$ & $\begin{array}{l}\text { Elsworth et al., } \\
2013 \text { [107] }\end{array}$ \\
\hline $\begin{array}{l}\text { Primary visual } \\
\text { cortex (V1) }\end{array}$ & $\begin{array}{l}\text { Rattus norvegicus } \\
\text { (males only) }\end{array}$ & $\begin{array}{l}\text { Reduced spine density and } \\
\text { maturity; decreased } \\
\text { interleukin } 1 \beta \text { (IL-1 } \beta \text { ) } \\
\text { expression; reduced P38 } \\
\text { phosphorylation }\end{array}$ & $\begin{array}{l}1 \mathrm{mg} / \mathrm{kg} / \text { day } \\
\text { (perinatal and } \\
\text { neonatal) }\end{array}$ & Hu et al., 2020 [102] \\
\hline $\begin{array}{l}\text { Basal ganglia } \\
\text { (dorsal striatum) }\end{array}$ & $\begin{array}{l}\text { Rattus norvegicus } \\
\text { (males only) }\end{array}$ & $\begin{array}{l}\text { Caused deficits in } \\
\text { development of LTP and LTD } \\
\text { at dorsolateral striatum; } \\
\text { dysregulated dopaminergic } \\
\text { signaling (D1R and D2R) }\end{array}$ & $\begin{array}{l}20 \mu \mathrm{g} / \mathrm{kg} / \text { day } \\
\text { (perinatal and } \\
\text { neonatal) }\end{array}$ & Zhou et al., 2009 [104] \\
\hline $\begin{array}{l}\text { Basolateral } \\
\text { amygdala } \\
\text { (BLA) }\end{array}$ & $\begin{array}{l}\text { Rattus norvegicus } \\
\text { (males only) }\end{array}$ & $\begin{array}{l}\text { Increased neuronal excitability } \\
\text { and facilitation of LTP } \\
\text { induction in cortical-BLA } \\
\text { pathway; GABAergic } \\
\text { disinhibition; dopaminergic } \\
\text { enhancement }\end{array}$ & $\begin{array}{c}2 \mu \mathrm{g} / \mathrm{kg} / \text { day } \\
\text { (perinatal) }\end{array}$ & Zhou et al., 2011 [103] \\
\hline
\end{tabular}

\section{Behavior Is Impacted by BPA}

Disruptions in neural development can have lasting effects on animal behavior. Consistent with the extensive impacts BPA elicits on the developing brain of laboratory animals, a variety of behavioral aberrations have been attributed to BPA exposure. Notably, many of the predominant BPA-associated behavioral outcomes are common endophenotypes of neurodevelopmental disorders, such as ADHD, ASD, and ID, including increased locomotor activity (hyperactivity), deficits in learning and memory, and increased anxiety-like behavior (Table 4). There are also studies indicating BPA causes contrasting phenotypes for each behavior; as with any toxicology study, these disparities may be due to differences in exposure regimen (dose, mode, and duration of exposure), genetic composition of the 
organism (even subtle genetic differences can alter an organism's response to environmental toxicants [121]), or experimental design, including differences in the age at which behavioral analysis occurred.

Despite differences in animal model and experimental design, studies examining locomotor activity have largely found developmental exposure to BPA gives rise to hyperactive progeny. At least eight separate studies using fruit flies [41,122,123], zebrafish [67,124,125], mice [126], and rats [103], found that when developing organisms were exposed to BPA, they exhibited increased locomotor activity as larvae/juveniles and/or as adults. In one study, BPA-associated hyperactivity was sex-specific and only observed in female mice [126], yet another study that solely examined locomotor activity in male rats detected hyperactive behavior [101]. Of the investigations attempting to delineate the cellular or molecular underpinnings of locomotor changes, studies using Drosophila and zebrafish attributed hyperactivity to BPA-mediated transcriptional changes in neurodevelopmental $[85,101]$ and metabolic pathways [101]. Another group attributed the BPA-associated hyperactivity in rats to increased neuronal excitability in the cortical-basolateral amygdala (BLA) pathway [103]. Studies of human brains found individuals with ADHD have altered connectivity between the amygdala and prefrontal cortex, in addition to smaller amygdalae [127]. Thus, the finding that BPA impacts the cortical-BLA pathway in rats points to a potential pathophysiological mechanism underlying the association between BPA exposure and ADHD in humans [51]. In contrast to the studies reporting BPA-associated hyperactivity, three studies using C. elegans (in a head thrashing test) [128], zebrafish (in swimming activity tests) [84], and rats (in an open-field test) [106] found BPA exposure caused hypoactivity.

Learning and memory involves the acquisition of information in response to environmental stimuli, which is encoded and stored in the brain for future retrieval. At least 14 studies have found early BPA exposure causes learning and memory deficits in offspring, in agreement with the many reports on BPA-associated diminishment of synaptogenesis and synaptic plasticity in the mammalian hippocampus described in preceding sections of this review. Avoidance learning and memory were found to be affected in female mice (only females were tested) [129], male mice (only males were tested) [110], and in male rats (both sexes were tested) [105]. Spatial learning and memory were disrupted by BPA in organisms ranging from zebrafish [125], mice [110], deer mice [130], and rats [101,105,106,131-136]; some studies reported sex-specific differences [130,131,135], some only tested one sex $[84,132]$, while others found no difference on the impact in male and female rodents $[101,105,125,126,133]$. Object recognition learning and memory in rodents was also impaired by BPA $[135,136]$. In contrast, contextual fear memory was enhanced in female mice exposed to BPA [137]. In Drosophila, learning was found to be disrupted in males (only males were tested) in an associative learning paradigm called conditioned courtship suppression [85]; while flies do not have a hippocampus, this finding is consistent with BPA-mediated axon guidance defects of the mushroom body [41].

Some of the proposed underlying molecular mechanisms of BPA-mediated learning and memory impairments in rodents include modulation of PKC/ERK and BDNF/CREB signaling cascades [105,129,135], and altered expression of NMDA receptor subunits $[105,106,110]$, AMPA receptor subunits [106], and critical pre/post-synaptic proteins [105,106], all of which can interfere with normal synaptic function. Finally, while the reasons for the disparities are unclear, some investigations found BPA had no impact on learning and memory in rodents, including two studies that reported no observed effects on spatial learning and memory [138,139], and another that found avoidance learning was intact [140].

Studies aimed at determining whether BPA causes anxiety have predominantly found developmental exposure leads to increased anxiety-like behaviors in offspring, often in a sex-specific manner. Three investigations using rodents of both sexes identified an increase in anxiety-like behaviors in males but not females [131,140,141]. Another study exclusively used male rodents and found similar BPA-mediated increases in anxiety-like behavior [109]. Only one study noted anxiety was increased in female rodents exposed to 
BPA but not males [133], and one investigation found that BPA led to a reduction in anxiety in both sexes [134]. These two studies used a Y-maze test, while all of the aforementioned studies used the open field test and/or elevated plus maze test to measure anxiety-like behavior; thus, the discrepancy may relate to the experimental modality and suggests using multiple paradigms within each study is warranted. Of the groups that identified BPAassociated anxiety-like behavior, Kumar et al. found perinatal exposure to BPA alters the ratio of excitatory to inhibitory synaptic densities [109]. Imbalances in neural excitation and inhibition have been reported in the pathophysiology of many neuropsychiatric disorders, including ASD, ADHD, schizophrenia, and epilepsy [142-144]. Thus, if BPA can indeed disrupt the excitation/inhibition balance, developmental exposure poses risk for numerous mental disorders.

Several recent reviews have also discussed neurobehavioral ramifications of BPA exposure in animal models [145-149]. Although not reviewed here, many other behaviors have been associated with early BPA exposure, including visual perception [85,102], depression-like behavior $[140,150]$, and social and reproductive behaviors $[141,146,151]$.

Table 4. Summary of studies that have investigated the impact of BPA on animal behavior.

\begin{tabular}{|c|c|c|c|c|}
\hline Behavior & Organism & Phenotype & Exposure & Reference \\
\hline \multirow{11}{*}{$\begin{array}{l}\text { Locomotor } \\
\text { Behavior }\end{array}$} & $\begin{array}{c}\text { Caenorhabditis } \\
\text { elegans }\end{array}$ & Reduced activity & $\begin{array}{c}0.01-10 \mathrm{mM} \\
\text { (developmental) }\end{array}$ & Zhou et al., 2016 [128] \\
\hline & $\begin{array}{l}\text { Drosophila } \\
\text { melanogaster }\end{array}$ & Increased activity & $\begin{array}{c}0.1-1 \mathrm{mM} \\
\text { (developmental) }\end{array}$ & $\begin{array}{l}\text { Musachio et al., } \\
\text { 2021 [122] }\end{array}$ \\
\hline & $\begin{array}{l}\text { Drosophila } \\
\text { melanogaster }\end{array}$ & Increased activity & $\begin{array}{c}\text { 0.1-1 mM } \\
\text { (developmental) }\end{array}$ & Nguyen et al., 2021 [41] \\
\hline & $\begin{array}{l}\text { Drosophila } \\
\text { melanogaster }\end{array}$ & Increased activity & $\begin{array}{c}0.1-1 \mathrm{mM} \\
\text { (developmental) }\end{array}$ & Kaur et al., 2015 [123] \\
\hline & Danio rerio & $\begin{array}{l}\text { Increased activity } \\
\text { (specifically in } \\
\text { response to } 0.001 \mu \mathrm{M} \text { BPA) }\end{array}$ & $\begin{array}{l}0.1 \mathrm{nM} \text { to } 30 \mu \mathrm{M} \\
\text { (developmental) }\end{array}$ & Olsvik et al., 2019 [124] \\
\hline & Danio rerio & Increased activity & $\begin{array}{l}0.01,0.1 \text {, or } 1 \mu \mathrm{M} \\
\text { (developmental) }\end{array}$ & Saili et al., 2012 [125] \\
\hline & Danio rerio & Increased activity & $\begin{array}{l}0.1 \text { or } 1 \mu \mathrm{M} \text { BPA } \\
\text { (developmental) }\end{array}$ & Kinch et al., 2015 [67] \\
\hline & Danio rerio & Reduced activity & $\begin{array}{c}1,5 \text {, or } 15 \mu \mathrm{M} \\
\text { (developmental) }\end{array}$ & Wang et al., 2013 [84] \\
\hline & Mus musculus & $\begin{array}{c}\text { Increased activity } \\
\text { in females } \\
\text { (not affected in males) }\end{array}$ & $\begin{array}{c}50 \mathrm{ng}, 50 \mu \mathrm{g}, \text { or } 50 \mathrm{mg} \\
\mathrm{BPA} / \mathrm{kg} / \text { day (perinatal) }\end{array}$ & $\begin{array}{c}\text { Anderson et al., } \\
2013 \text { [126] }\end{array}$ \\
\hline & $\begin{array}{l}\text { Rattus norvegicus } \\
\text { (males only) }\end{array}$ & Increased activity & $\begin{array}{c}2 \mu \mathrm{g} / \mathrm{kg} / \text { day } \\
\text { (perinatal) }\end{array}$ & Zhou et al., 2011 [103] \\
\hline & $\begin{array}{l}\text { Rattus norvegicus } \\
\text { (males only) }\end{array}$ & Reduced activity & $\begin{array}{l}0.05,0.5,5, \text { or } \\
50 \mathrm{mg} / \mathrm{kg} / \text { day } \\
\quad \text { (perinatal) }\end{array}$ & Wang et al., 2014 [106] \\
\hline \multirow{3}{*}{$\begin{array}{l}\text { Learning \& } \\
\text { Memory }\end{array}$} & $\begin{array}{l}\text { Drosophila } \\
\text { melanogaster } \\
\text { (males only) }\end{array}$ & $\begin{array}{l}\text { Impaired associative } \\
\text { learning }\end{array}$ & $\begin{array}{c}1 \mathrm{mM} \\
\text { (developmental) }\end{array}$ & Welch et al., 2022 [85] \\
\hline & Danio rerio & Impaired learning & $\begin{array}{l}0.01,0.1, \text { or } 1 \mu \mathrm{M} \\
\text { (developmental) }\end{array}$ & Saili et al., 2012 [125] \\
\hline & Mus musculus & $\begin{array}{c}\text { Enhanced fear memory in } \\
\text { females; no observed effect in } \\
\text { males }\end{array}$ & $\begin{array}{l}250 \mathrm{ng} / \mathrm{kg} / \text { day } \\
\text { (perinatal) }\end{array}$ & $\begin{array}{l}\text { Matsuda et al., } \\
2013 \text { [137] }\end{array}$ \\
\hline
\end{tabular}


Table 4. Cont

\begin{tabular}{|c|c|c|c|c|}
\hline Behavior & Organism & Phenotype & Exposure & Reference \\
\hline & $\begin{array}{l}\text { Mus musculus } \\
\text { (females only) }\end{array}$ & Impaired memory retention & $\begin{array}{l}0.1-10 \mathrm{mg} / \mathrm{kg} / \text { day } \\
\text { (prenatal) }\end{array}$ & Jang et al., 2012 [129] \\
\hline & Mus musculus & $\begin{array}{l}\text { No observed effect on spatial } \\
\text { learning and memory }\end{array}$ & $\begin{array}{c}20 \mu \mathrm{g} / \mathrm{kg} / \text { day } \\
\text { (perinatal) }\end{array}$ & $\begin{array}{l}\text { Nakamura et al., } \\
2012 \text { [138] }\end{array}$ \\
\hline & $\begin{array}{l}\text { Mus musculus } \\
\text { (males only) }\end{array}$ & $\begin{array}{c}\text { Impaired spatial and } \\
\text { avoidance memory }\end{array}$ & $\begin{array}{c}0.05-50 \mathrm{mg} / \mathrm{kg} / \text { day } \\
\text { (perinatal) }\end{array}$ & Xu et al., 2010 [110] \\
\hline & $\begin{array}{l}\text { Peromyscus } \\
\text { maniculatus } \\
\text { (deer mice) }\end{array}$ & $\begin{array}{c}\text { Impaired spatial learning in } \\
\text { males at } 5 \text { and } 50 \mathrm{mg} / \mathrm{kg} \text {, } \\
\text { no observed } \\
\text { effect in females }\end{array}$ & $\begin{array}{l}\text { One or three doses of } \\
\text { BPA at } 50 \mu \mathrm{g}, 5 \mathrm{mg} \text {, and } \\
50 \mathrm{mg} / \mathrm{kg} \text { feed weight }\end{array}$ & $\begin{array}{l}\text { Jašarević et al., } \\
2012 \text { [130] }\end{array}$ \\
\hline & Rattus norvegicus & $\begin{array}{l}\text { Impaired spatial and } \\
\text { recognition memory } \\
\text { in males and females; } \\
\text { Impaired passive } \\
\text { avoidance memory in males }\end{array}$ & $\begin{array}{c}1 \text { and } 10 \mu \mathrm{g} / \mathrm{mL} \text {, } \\
\text { equivalent to } 0.14 \text { or } \\
1.4 \mathrm{mg} / \mathrm{kg} / \text { day } \\
\text { (perinatal) }\end{array}$ & Wu et al., 2020 [105] \\
\hline & $\begin{array}{l}\text { Rattus norvegicus } \\
\quad \text { (males only) }\end{array}$ & $\begin{array}{l}\text { Impaired object } \\
\text { recognition memory }\end{array}$ & $\begin{array}{c}0.05,0.5,5, \text { or } \\
50 \mathrm{mg} / \mathrm{kg} / \text { day } \\
\text { (prenatal) }\end{array}$ & Wang et al., 2016 [135] \\
\hline & Rattus norvegicus & $\begin{array}{l}\text { Impaired spatial memory in } \\
\text { both males and females }\end{array}$ & $\begin{array}{c}0.15-7.5 \mathrm{mg} / \mathrm{kg} / \text { day } \\
\text { (prenatal and postnatal, } \\
\text { through } \\
\text { PND 87) }\end{array}$ & Liu et al., 2016 [101] \\
\hline & Rattus norvegicus & $\begin{array}{l}\text { Impaired spatial recognition } \\
\text { learning and memory in } \\
\text { females at } 2500 \mu \mathrm{g} / \mathrm{kg} / \text { day }\end{array}$ & $\begin{array}{l}2.5 \mu \mathrm{g}, 25 \mu \mathrm{g} \text {, and } \\
2500 \mu \mathrm{g} / \mathrm{kg} / \text { day } \\
\quad \text { (perinatal) }\end{array}$ & $\begin{array}{l}\text { Johnson et al., } \\
2016 \text { [131] }\end{array}$ \\
\hline & Rattus norvegicus & $\begin{array}{l}\text { Altered spatial learning of } \\
\text { females at } 25 \mu \mathrm{g} / \mathrm{kg} / \mathrm{day} \\
\text { (masculinization of } \\
\text { female brain) }\end{array}$ & $\begin{array}{c}0,25 \mu \mathrm{g}, 250 \mu \mathrm{g}, 5 \mathrm{mg}, \text { or } \\
50 \mathrm{mg} / \mathrm{kg} / \text { day } \\
\text { (perinatal) }\end{array}$ & Hass et al., 2016 [136] \\
\hline & $\begin{array}{l}\text { Rattus norvegicus } \\
\quad \text { (males only) }\end{array}$ & $\begin{array}{l}\text { Impaired working and } \\
\text { reference memory }\end{array}$ & $\begin{array}{c}0.05,0.5,5, \text { or } \\
50 \mathrm{mg} / \mathrm{kg} / \text { day } \\
\text { (perinatal) }\end{array}$ & Wang et al., 2014 [106] \\
\hline & $\begin{array}{l}\text { Rattus norvegicus } \\
\text { (males only) }\end{array}$ & Impaired spatial memory & $\begin{array}{l}2.5 \mathrm{mg} / \mathrm{kg} / \text { day } \\
\text { (perinatal) }\end{array}$ & Xu et al., 2014 [132] \\
\hline & Rattus norvegicus & $\begin{array}{l}\text { Impaired spatial memory in } \\
\text { both males and females }\end{array}$ & $\begin{array}{l}40 \mathrm{ug} / \mathrm{kg} / \text { day } \\
\text { (perinatal) }\end{array}$ & $\begin{array}{l}\text { Poimenova et al., } \\
2010 \text { [133] }\end{array}$ \\
\hline & Rattus norvegicus & $\begin{array}{c}\text { No effect on avoidance } \\
\text { learning }\end{array}$ & $\begin{array}{c}15 \mu \mathrm{g} / \mathrm{kg} / \text { day } \\
\text { (prenatal) }\end{array}$ & $\begin{array}{c}\text { Fujimoto et al., } \\
2006[140]\end{array}$ \\
\hline & Rattus norvegicus & $\begin{array}{l}\text { Impaired working } \\
\text { memory and object } \\
\text { recognition memory }\end{array}$ & $\begin{array}{c}100 \text { or } 500 \mu \mathrm{g} / \mathrm{kg} / \text { day } \\
\text { (perinatal) }\end{array}$ & Tian et al., 2010 [134] \\
\hline \multirow{3}{*}{$\begin{array}{l}\text { Anxiety-Like } \\
\text { Behavior }\end{array}$} & $\begin{array}{l}\text { Mus musculus } \\
\text { (males only) }\end{array}$ & Increased & $\begin{array}{c}50 \mu \mathrm{g} / \mathrm{kg} / \text { day } \\
\text { (perinatal) }\end{array}$ & $\begin{array}{l}\text { Kumar and Thakur, } \\
2017 \text { [109] }\end{array}$ \\
\hline & Mus musculus & $\begin{array}{l}\text { Increased in males, } \\
\text { no effect in } \\
\text { females }\end{array}$ & $\begin{array}{l}50 \mathrm{mg} / \mathrm{kg} / \text { day } \\
\quad \text { (prenatal) }\end{array}$ & Cox et al., 2010 [141] \\
\hline & $\begin{array}{l}\text { Peromyscus } \\
\text { maniculatus } \\
\text { (deer mice) }\end{array}$ & $\begin{array}{c}\text { Increased in males at } \\
5 \text { and } 50 \mathrm{mg} / \mathrm{kg}, \\
\text { no observed effect } \\
\text { in females }\end{array}$ & $\begin{array}{l}\text { One or three doses of } \\
\text { BPA at } 50 \mu \mathrm{g}, 5 \mathrm{mg} \text {, and } \\
50 \mathrm{mg} / \mathrm{kg} \text { feed weight }\end{array}$ & $\begin{array}{l}\text { Jašarević et al., } \\
2012 \text { [130] }\end{array}$ \\
\hline
\end{tabular}


Table 4. Cont.

\begin{tabular}{|c|c|c|c|c|}
\hline Behavior & Organism & Phenotype & Exposure & Reference \\
\hline & Rattus norvegicus & $\begin{array}{c}\text { Increased in females, } \\
\text { no effect in males }\end{array}$ & $\begin{array}{l}40 \mathrm{ug} / \mathrm{kg} / \text { day } \\
\text { (perinatal) }\end{array}$ & $\begin{array}{l}\text { Poimenova et al., } \\
2010 \text { [133] }\end{array}$ \\
\hline & Rattus norvegicus & No observed effect & $\begin{array}{l}0.15,1.5,75,750, \text { and } \\
2250 \text { ppm (perinatal) }\end{array}$ & Stump et al., 2010 [139] \\
\hline & Rattus norvegicus & Reduced anxiety & $\begin{array}{c}100 \text { or } 500 \mu \mathrm{g} / \mathrm{kg} / \mathrm{day} \\
\text { (perinatal) }\end{array}$ & Tian et al., 2010 [134] \\
\hline & Rattus norvegicus & $\begin{array}{l}\text { Increased in males, } \\
\text { no effect in females }\end{array}$ & $\begin{array}{c}15 \mu \mathrm{g} / \mathrm{kg} / \mathrm{day} \\
\text { (prenatal) }\end{array}$ & $\begin{array}{l}\text { Fujimoto et al., } \\
2006[140]\end{array}$ \\
\hline
\end{tabular}

\section{Conclusions}

This review described the neurodevelopmental impacts-molecular, cellular, and behavioral-resulting from early exposure to BPA in organisms spanning the animal kingdom, from invertebrates to mammals. While the laboratory animals used in these studies largely served as models for understanding human impacts of BPA exposure, it should be emphasized that BPA clearly impaired the neurodevelopment of organisms throughout our environment, suggesting broad implications for the ecosystem.

Behavioral changes caused by BPA in animal models are largely consistent with human behaviors associated with BPA exposure, including hyperactivity, learning deficits, and anxiety-like behavior. In animal models, the neurodevelopmental impacts associated with both low and high dose exposure to BPA during development are vast, beginning with interruptions in NSC development and extending to axon growth and guidance defects, impaired dendritogenesis, and altered synaptic plasticity. The findings presented in this review collectively indicate that developmental exposure to BPA should be regarded as a risk factor for NDDs in humans.

Author Contributions: C.W. and K.M. both made substantial contributions to the writing and editing of this review. All authors have read and agreed to the published version of the manuscript.

Funding: Publication charges were supported by the National Institute of General Medical Sciences of the National Institutes of Health under award number 5 SC2 GM132005.

Institutional Review Board Statement: Not applicable.

Informed Consent Statement: Not applicable.

Data Availability Statement: Not applicable.

Conflicts of Interest: The authors declare no conflict of interest.

\section{References}

1. Zablotsky, B.; Black, L.I.; Maenner, M.J.; Schieve, L.A.; Danielson, M.L.; Bitsko, R.H.; Blumberg, S.J.; Kogan, M.D.; Boyle, C.A. Prevalence and Trends of Developmental Disabilities among Children in the United States: 2009-2017. Pediatrics 2019, 144, e20190811. [CrossRef] [PubMed]

2. Baio, J.; Wiggins, L.; Christensen, D.L.; Maenner, M.J.; Daniels, J.; Warren, Z.; Kurzius-Spencer, M.; Zahorodny, W.; Robinson, C.R.; Rosenberg, C.R.; et al. Prevalence of Autism Spectrum Disorder Among Children Aged 8 Years-Autism and Developmental Disabilities Monitoring Network, 11 Sites, United States, 2014. MMWR. Surveill. Summ. 2018, 67, 1-23. [CrossRef] [PubMed]

3. Maenner, M.J.; Shaw, K.A.; Baio, J.; Washington, A.; Patrick, M.; DiRienzo, M.; Christensen, D.L.; Wiggins, L.D.; Pettygrove, S.; Andrews, J.G.; et al. Prevalence of Autism Spectrum Disorder Among Children Aged 8 Years-Autism and Developmental Disabilities Monitoring Network, 11 Sites, United States, 2016. Morb. Mortal. Wkly. Rep. Surveill. Summ. 2020, 69, 1-12. [CrossRef] [PubMed]

4. Herbert, M.R. Contributions of the environment and environmentally vulnerable physiology to autism spectrum disorders. Curr. Opin. Neurol. 2010, 23, 103-110. [CrossRef]

5. Matelski, L.; Van de Water, J. Risk factors in autism: Thinking outside the brain. J. Autoimmun. 2016, 67, 1-7. [CrossRef]

6. Almeida, S.; Raposo, A.; Almeida-González, M.; Carrascosa, C. Bisphenol A: Food Exposure and Impact on Human Health. Compr. Rev. Food Sci. Food Saf. 2018, 17, 1503-1517. [CrossRef] 
7. De Cock, M.; Maas, Y.G.; Van De Bor, M. Does perinatal exposure to endocrine disruptors induce autism spectrum and attention deficit hyperactivity disorders? Review. Acta Paediatr. 2012, 101, 811-818. [CrossRef]

8. Minatoya, M.; Kishi, R. A Review of Recent Studies on Bisphenol A and Phthalate Exposures and Child Neurodevelopment. Int J. Environ. Res. Public Health 2021, 18, 3585. [CrossRef]

9. Mustieles, V.; Fernández, M.F. Bisphenol A shapes children's brain and behavior: Towards an integrated neurotoxicity assessment including human data. Environ. Health 2020, 19, 66. [CrossRef]

10. Wetherill, Y.B.; Akingbemi, B.T.; Kanno, J.; McLachlan, J.A.; Nadal, A.; Sonnenschein, C.; Watson, C.S.; Zoeller, R.T.; Belcher, S.M. In vitro molecular mechanisms of bisphenol A action. Reprod. Toxicol. 2007, 24, 178-198. [CrossRef]

11. Bonefeld-Jørgensen, E.C.; Long, M.; Hofmeister, M.V.; Vinggaard, A.M. Endocrine-Disrupting Potential of Bisphenol A, Bisphenol A Dimethacrylate, 4-N-Nonylphenol, and 4-N-Octylphenolin Vitro: New Data and a Brief Review. Environ. Health Perspect. 2007, 115, 69-76. [CrossRef] [PubMed]

12. Moriyama, K.; Tagami, T.; Akamizu, T.; Usui, T.; Saijo, M.; Kanamoto, N.; Hataya, Y.; Shimatsu, A.; Kuzuya, H.; Nakao, K. Thyroid Hormone Action Is Disrupted by Bisphenol A as an Antagonist. J. Clin. Endocrinol. Metab. 2002, 87, 5185-5190. [CrossRef] [PubMed]

13. Sun, H.; Shen, O.-X.; Wang, X.-R.; Zhou, L.; Zhen, S.-Q.; Chen, X.-D. Anti-thyroid hormone activity of bisphenol A, tetrabromobisphenol A and tetrachlorobisphenol A in an improved reporter gene assay. Toxicol. Vitr. 2009, 23, 950-954. [CrossRef]

14. Wang, J.; Sun, B.; Hou, M.; Pan, X.; Li, X. The environmental obesogen bisphenol A promotes adipogenesis by increasing the amount of 11ß-hydroxysteroid dehydrogenase type 1 in the adipose tissue of children. Int. J. Obes. 2012, 37, 999-1005. [CrossRef] [PubMed]

15. Prasanth, G.K.; Divya, L.M.; Sadasivan, C. Bisphenol-A can bind to human glucocorticoid receptor as an agonist: An in silico study. J. Appl. Toxicol. 2010, 30, 769-774. [CrossRef] [PubMed]

16. Atlas, E.; Pope, L.; Wade, M.G.; Kawata, A.; Boudreau, A.; Boucher, J.G. Bisphenol A increases aP2 expression in 3T3L1 by enhancing the transcriptional activity of nuclear receptors at the promoter. Adipocyte 2014, 3, 170-179. [CrossRef] [PubMed]

17. Thomas, P.; Dong, J. Binding and activation of the seven-transmembrane estrogen receptor GPR30 by environmental estrogens: A potential novel mechanism of endocrine disruption. J. Steroid Biochem. Mol. Biol. 2006, 102, 175-179. [CrossRef]

18. Pereira-Fernandes, A.; Demaegdt, H.; Vandermeiren, K.; Hectors, T.L.M.; Jorens, P.G.; Blust, R.; Vanparys, C. Evaluation of a Screening System for Obesogenic Compounds: Screening of Endocrine Disrupting Compounds and Evaluation of the PPAR Dependency of the Effect. PLoS ONE 2013, 8, e77481. [CrossRef]

19. Somm, E.; Schwitzgebel, V.M.; Toulotte, A.; Cederroth, C.R.; Combescure, C.; Nef, S.; Aubert, M.L.; Hüppi, P.S. Perinatal Exposure to Bisphenol A Alters Early Adipogenesis in the Rat. Environ. Health Perspect. 2009, 117, 1549-1555. [CrossRef]

20. Vogel, S.A. The Politics of Plastics: The Making and Unmaking of Bisphenol A "Safety". Am. J. Public Health 2009, 99, S559-S566. [CrossRef]

21. Dodds, E.C.; Lawson, W. Synthetic strogenic Agents without the Phenanthrene Nucleus. Nature 1936, 137, 996. [CrossRef]

22. Vandenberg, L.N.; Maffini, M.V.; Sonnenschein, C.; Rubin, B.S.; Soto, A.M. Bisphenol-A and the Great Divide: A Review of Controversies in the Field of Endocrine Disruption. Endocr. Rev. 2009, 30, 75-95. [CrossRef] [PubMed]

23. Nerín, C.; Fernández, C.; Domeño, C.; Salafranca, J. Determination of Potential Migrants in Polycarbonate Containers Used for Microwave Ovens by High-Performance Liquid Chromatography with Ultraviolet and Fluorescence Detection. J. Agric. Food Chem. 2003, 51, 5647-5653. [CrossRef] [PubMed]

24. Brede, C.; Fjeldal, P.; Skjevrak, I.; Herikstad, H. Increased migration levels of bisphenol A from polycarbonate baby bottles after dishwashing, boiling and brushing. Food Addit. Contam. 2003, 20, 684-689. [CrossRef] [PubMed]

25. Konieczna, A.; Rutkowska, A.; Rachon, D. Health risk of exposure to Bisphenol A (BPA). Rocz. Panstw. Zakl. Hig. 2015, 66, 5-11.

26. Liao, C.; Kannan, K. Concentrations and Profiles of Bisphenol A and Other Bisphenol Analogues in Foodstuffs from the United States and Their Implications for Human Exposure. J. Agric. Food Chem. 2013, 61, 4655-4662. [CrossRef]

27. Liao, C.; Kannan, K. A Survey of Alkylphenols, Bisphenols, and Triclosan in Personal Care Products from China and the United States. Arch. Environ. Contam. Toxicol. 2014, 67, 50-59. [CrossRef]

28. Pivnenko, K.; Pedersen, G.A.; Eriksson, E.; Astrup, T. Bisphenol A and its structural analogues in household waste paper. Waste Manag. 2015, 44, 39-47. [CrossRef]

29. Balakrishnan, B.; Henare, K.; Thorstensen, E.B.; Ponnampalam, A.P.; Mitchell, M.D. Transfer of bisphenol A across the human placenta. Am. J. Obstet. Gynecol. 2010, 202, 393.e1-393.e7. [CrossRef]

30. Sun, Y.; Nakashima, M.N.; Takahashi, M.; Kuroda, N.; Nakashima, K. Determination of bisphenol A in rat brain by microdialysis and column switching high-performance liquid chromatography with fluorescence detection. Biomed. Chromatogr. 2002, 16, 319-326. [CrossRef]

31. Nishikawa, M.; Iwano, H.; Yanagisawa, R.; Koike, N.; Inoue, H.; Yokota, H. Placental Transfer of Conjugated Bisphenol A and Subsequent Reactivation in the Rat Fetus. Environ. Health Perspect. 2010, 118, 1196-1203. [CrossRef] [PubMed]

32. LaKind, J.S.; Levesque, J.; Dumas, P.; Bryan, S.N.; Clarke, J.; Naiman, D.Q. Comparing United States and Canadian population exposures from National Biomonitoring Surveys: Bisphenol A intake as a case study. J. Expo. Sci. Environ. Epidemiol. 2012, 22, 219-226. [CrossRef] [PubMed] 
33. Eladak, S.; Grisin, T.; Moison, D.; Guerquin, M.-J.; N’Tumba-Byn, T.; Pozzi-Gaudin, S.; Benachi, A.; Livera, G.; Rouiller-Fabre, V.; Habert, R. A new chapter in the bisphenol A story: Bisphenol $\mathrm{S}$ and bisphenol $\mathrm{F}$ are not safe alternatives to this compound. Fertil. Steril. 2015, 103, 11-21. [CrossRef] [PubMed]

34. Hessel, E.V.; Ezendam, J.; van Broekhuizen, F.A.; Hakkert, B.; DeWitt, J.; Granum, B.; Guzylack, L.; Lawrence, B.P.; Penninks, A.; Rooney, A.A.; et al. Assessment of recent developmental immunotoxicity studies with bisphenol A in the context of the 2015 EFSA t-TDI. Reprod. Toxicol. 2016, 65, 448-456. [CrossRef] [PubMed]

35. Negri-Cesi, P. Bisphenol A Interaction with Brain Development and Functions. Dose-Response 2015, 13, 1559325815590394 [CrossRef] [PubMed]

36. Geens, T.; Roosens, L.; Neels, H.; Covaci, A. Assessment of human exposure to Bisphenol-A, Triclosan and Tetrabromobisphenol-A through indoor dust intake in Belgium. Chemosphere 2009, 76, 755-760. [CrossRef] [PubMed]

37. Corrales, J.; Kristofco, L.A.; Steele, W.B.; Yates, B.S.; Breed, C.S.; Williams, E.S.; Brooks, B.W. Global Assessment of Bisphenol A in the Environment: Review and Analysis of Its Occurrence and Bioaccumulation. Dose-Response 2015, 13, 1559325815598308. [CrossRef]

38. Nahar, M.S.; Liao, C.; Kannan, K.; Dolinoy, D.C. Fetal Liver Bisphenol A Concentrations and Biotransformation Gene Expression Reveal Variable Exposure and Altered Capacity for Metabolism in Humans. J. Biochem. Mol. Toxicol. 2012, 27, 116-123. [CrossRef]

39. Vandenberg, L.N. Non-Monotonic Dose Responses in Studies of Endocrine Disrupting Chemicals: Bisphenol a as a Case Study. Dose-Response 2013, 12, 259-276. [CrossRef]

40. Villar-Pazos, S.; Martinez-Pinna, J.; Castellano-Muñoz, M.; Magdalena, P.A.; Marroqui, L.; Quesada, I.; Gustafsson, J.-A.; Nadal, A. Molecular mechanisms involved in the non-monotonic effect of bisphenol-a on $\mathrm{Ca}^{2+}$ entry in mouse pancreatic $\beta$-cells. Sci. Rep. 2017, 7, 11700. [CrossRef]

41. Nguyen, U.; Tinsley, B.; Sen, Y.; Stein, J.; Palacios, Y.; Ceballos, A.; Welch, C.; Nzenkue, K.; Penn, A.; Murphy, L.; et al. Exposure to bisphenol A differentially impacts neurodevelopment and behavior in Drosophila melanogaster from distinct genetic backgrounds. Neuro Toxicol. 2020, 82, 146-157. [CrossRef] [PubMed]

42. Gore, A.C. Neuroendocrine targets of endocrine disruptors. Hormones 2010, 9, 16-27. [CrossRef]

43. Casas, M.; Forns, J.; Martínez, D.; Avella-García, C.; Valvi, D.; Ballesteros-Gómez, A.; Luque, N.; Rubio, S.; Julvez, J.; Sunyer, J.; et al. Exposure to bisphenol A during pregnancy and child neuropsychological development in the INMA-Sabadell cohort. Environ. Res. 2015, 142, 671-679. [CrossRef] [PubMed]

44. Lin, C.-C.; Chien, C.-J.; Tsai, M.-S.; Hsieh, C.-J.; Hsieh, W.-S.; Chen, P.-C. Prenatal phenolic compounds exposure and neurobehavioral development at 2 and 7 years of age. Sci. Total Environ. 2017, 605-606, 801-810. [CrossRef] [PubMed]

45. Jensen, T.K.; Mustieles, V.; Bleses, D.; Frederiksen, H.; Trecca, F.; Schoeters, G.; Andersen, H.R.; Grandjean, P.; Kyhl, H.B.; Juul, A.; et al. Prenatal bisphenol A exposure is associated with language development but not with ADHD-related behavior in toddlers from the Odense Child Cohort. Environ. Res. 2019, 170, 398-405. [CrossRef] [PubMed]

46. Stacy, S.; Papandonatos, G.; Calafat, A.M.; Chen, A.; Yolton, K.; Lanphear, B.P.; Braun, J.M. Early life bisphenol A exposure and neurobehavior at 8 years of age: Identifying windows of heightened vulnerability. Environ. Int. 2017, 107, 258-265. [CrossRef]

47. Perera, F.; Nolte, E.L.R.; Wang, Y.; Margolis, A.E.; Calafat, A.M.; Wang, S.; Garcia, W.; Hoepner, L.A.; Peterson, B.S.; Rauh, V.; et al. Bisphenol A exposure and symptoms of anxiety and depression among inner city children at 10-12 years of age. Environ. Res. 2016, 151, 195-202. [CrossRef]

48. Stein, T.P.; Schluter, M.D.; Steer, R.A.; Guo, L.; Ming, X. Bisphenol A Exposure in Children With Autism Spectrum Disorders. Autism Res. 2015, 8, 272-283. [CrossRef]

49. Rahbar, M.H.; Swingle, H.M.; Christian, M.A.; Hessabi, M.; Lee, M.; Pitcher, M.R.; Campbell, S.; Mitchell, A.; Krone, R.; Loveland, K.A.; et al. Environmental Exposure to Dioxins, Dibenzofurans, Bisphenol A, and Phthalates in Children with and without Autism Spectrum Disorder Living near the Gulf of Mexico. Int. J. Environ. Res. Public Health 2017, 14, 1425. [CrossRef]

50. Li, Y.; Zhang, H.; Kuang, H.; Fan, R.; Cha, C.; Li, G.; Luo, Z.; Pang, Q. Relationship between bisphenol A exposure and attentiondeficit/ hyperactivity disorder: A case-control study for primary school children in Guangzhou, China. Environ. Pollut. 2018, 235, 141-149. [CrossRef]

51. Tewar, S.; Auinger, P.; Braun, J.M.; Lanphear, B.; Yolton, K.; Epstein, J.N.; Ehrlich, S.; Froehlich, T.E. Association of Bisphenol A exposure and Attention-Deficit/Hyperactivity Disorder in a national sample of U.S. children. Environ. Res. 2016, 150, 112-118. [CrossRef] [PubMed]

52. Grohs, M.N.; the APrON Study Team; Reynolds, J.E.; Liu, J.; Martin, J.; Pollock, T.; Lebel, C.; Dewey, D. Prenatal maternal and childhood bisphenol a exposure and brain structure and behavior of young children. Environ. Health 2019, 18, 85. [CrossRef] [PubMed]

53. Sun, D.; Zhou, X.; Yu, H.-L.; He, X.-X.; Guo, W.-X.; Xiong, W.-C.; Zhu, X.-J. Regulation of neural stem cell proliferation and differentiation by Kinesin family member 2a. PLoS ONE 2017, 12, e0179047. [CrossRef] [PubMed]

54. Tiwari, S.K.; Agarwal, S.; Seth, B.; Yadav, A.; Ray, R.S.; Mishra, V.N.; Chaturvedi, R.K. Inhibitory Effects of Bisphenol-A on Neural Stem Cells Proliferation and Differentiation in the Rat Brain Are Dependent on Wnt/ $\beta$-Catenin Pathway. Mol. Neurobiol. 2015, 52, 1735-1757. [CrossRef] [PubMed]

55. Urbã in, N.; Guillemot, F. Neurogenesis in the embryonic and adult brain: Same regulators, different roles. Front. Cell. Neurosci. 2014, 8, 396. [CrossRef] [PubMed] 
56. Shohayeb, B.; Diab, M.; Ahmed, M.; Ng, D.C.H. Factors that influence adult neurogenesis as potential therapy. Transl. Neurodegener. 2018, 7, 4. [CrossRef]

57. Ernst, C. Proliferation and Differentiation Deficits are a Major Convergence Point for Neurodevelopmental Disorders. Trends Neurosci. 2016, 39, 290-299. [CrossRef]

58. Stevens, H.E.; Smith, K.M.; Rash, B.; Vaccarino, F.M. Neural stem cell regulation, fibroblast growth factors, and the developmental origins of neuropsychiatric disorders. Front. Neurosci. 2010, 4, 59. [CrossRef]

59. Smith, I.; Nakashima, K. Mechanisms of Neural Stem Cell Fate Determination: Extracellular Cues and Intracellular Programs. Curr. Stem Cell Res. Ther. 2006, 1, 267-277. [CrossRef]

60. Kong, S.-Y.; Park, M.-H.; Lee, M.; Kim, J.-O.; Lee, H.-R.; Han, B.W.; Svendsen, C.N.; Sung, S.H.; Kim, H.-J. Kuwanon V Inhibits Proliferation, Promotes Cell Survival and Increases Neurogenesis of Neural Stem Cells. PLoS ONE 2015, 10, e0118188. [CrossRef]

61. Longo, F.M.; Yang, T.; Xie, Y.; Massa, S.M. Small Molecule Approaches for Promoting Neurogenesis. Curr. Alzheimer Res. 2006, 3 , 5-10. [CrossRef] [PubMed]

62. Kim, H.-J.; Rosenfeld, M.G. Epigenetic control of stem cell fate to neurons and glia. Arch. Pharmacal Res. 2010, $33,1467-1473$. [CrossRef] [PubMed]

63. Kim, H.-J.; Jin, C.Y. Stem Cells in Drug Screening for Neurodegenerative Disease. Korean J. Physiol. Pharmacol. 2012, 16, 1-9. [CrossRef]

64. Yoon, H.J.; Kong, S.-Y.; Park, M.-H.; Cho, Y.; Kim, S.-E.; Shin, J.-Y.; Jung, S.; Lee, J.; Farhanullah; Kim, H.-J.; et al. Aminopropyl carbazole analogues as potent enhancers of neurogenesis. Bioorganic Med. Chem. 2013, 21, 7165-7174. [CrossRef]

65. Kim, H.J.; Leeds, P.; Chuang, D.-M. The HDAC inhibitor, sodium butyrate, stimulates neurogenesis in the ischemic brain. J. Neurochem. 2009, 110, 1226-1240. [CrossRef] [PubMed]

66. Saxe, J.P.; Wu, H.; Kelly, T.K.; Phelps, M.E.; Sun, Y.E.; Kornblum, H.I.; Huang, J. A Phenotypic Small-Molecule Screen Identifies an Orphan Ligand-Receptor Pair that Regulates Neural Stem Cell Differentiation. Chem. Biol. 2007, 14, 1019-1030. [CrossRef]

67. Kinch, C.D.; Ibhazehiebo, K.; Jeong, J.-H.; Habibi, H.R.; Kurrasch, D.M. Low-dose exposure to bisphenol A and replacement bisphenol S induces precocious hypothalamic neurogenesis in embryonic zebrafish. Proc. Natl. Acad. Sci. USA 2015, 112, 1475-1480. [CrossRef]

68. Gill, S.; Kumara, V. Comparative Neurodevelopment Effects of Bisphenol A and Bisphenol F on Rat Fetal Neural Stem Cell Models. Cells 2021, 10, 793. [CrossRef]

69. Cho, J.-H.; Kim, A.H.; Lee, S.; Lee, Y.; Lee, W.J.; Chang, S.-C.; Lee, J. Sensitive neurotoxicity assessment of bisphenol A using double immunocytochemistry of DCX and MAP2. Arch. Pharmacal Res. 2018, 41, 1098-1107. [CrossRef]

70. Huang, M.; Li, Y.; Wu, K.; Hao, S.; Cai, Q.; Zhou, Z.; Yang, H. Effects of environmental chemicals on the proliferation and differentiation of neural stem cells. Environ. Toxicol. 2019, 34, 1285-1291. [CrossRef]

71. Agarwal, S.; Yadav, A.; Tiwari, S.K.; Seth, B.; Chauhan, L.K.S.; Khare, P.; Ray, R.S.; Chaturvedi, R.K. Dynamin-related Protein 1 Inhibition Mitigates Bisphenol A-mediated Alterations in Mitochondrial Dynamics and Neural Stem Cell Proliferation and Differentiation. J. Biol. Chem. 2016, 291, 15923-15939. [CrossRef] [PubMed]

72. Kim, K.; Son, T.G.; Kim, S.J.; Kim, H.S.; Kim, T.S.; Han, S.Y.; Lee, J. Suppressive Effects of Bisphenol A on the Proliferation of Neural Progenitor Cells. J. Toxicol. Environ. Health Part A 2007, 70, 1288-1295. [CrossRef] [PubMed]

73. Dong, P.; Ye, G.; Tu, X.; Luo, Y.; Cui, W.; Ma, Y.; Wei, L.; Tian, X.; Wang, Q. Roles of ERR $\alpha$ and TGF- $\beta$ signaling in stemness enhancement induced by $1 \mu \mathrm{M}$ bisphenol A exposure via human neural stem cells. Exp. Ther. Med. 2021, 23, 164. [CrossRef] [PubMed]

74. Fujiwara, Y.; Miyazaki, W.; Koibuchi, N.; Katoh, T. The Effects of Low-Dose Bisphenol A and Bisphenol F on Neural Differentiation of a Fetal Brain-Derived Neural Progenitor Cell Line. Front. Endocrinol. 2018, 9, 24. [CrossRef]

75. Azari, H.; Reynolds, B.A. In Vitro Models for Neurogenesis. Cold Spring Harb. Perspect. Biol. 2015, 8, a021279. [CrossRef]

76. Santoro, A.; Scafuro, M.; Troisi, J.; Piegari, G.; Di Pietro, P.; Mele, E.; Cappetta, D.; Marino, M.; De Angelis, A.; Vecchione, C.; et al Multi-Systemic Alterations by Chronic Exposure to a Low Dose of Bisphenol A in Drinking Water: Effects on Inflammation and $\mathrm{NAD}^{+}$-Dependent Deacetylase Sirtuin1 in Lactating and Weaned Rats. Int. J. Mol. Sci. 2021, 22, 9666. [CrossRef]

77. Mulligan, K.A.; Cheyette, B.N. Neurodevelopmental Perspectives on Wnt Signaling in Psychiatry. Mol. Neuropsychiatry 2016, 2, 219-246. [CrossRef]

78. Mulligan, K.A.; Cheyette, B.N.R. Wnt Signaling in Vertebrate Neural Development and Function. J. Neuroimmune Pharmacol. 2012, 7,774-787. [CrossRef]

79. Hirabayashi, Y.; Gotoh, Y. Epigenetic control of neural precursor cell fate during development. Nat. Rev. Neurosci. 2010, 11, 377-388. [CrossRef]

80. Batool, S.; Raza, H.; Zaidi, J.; Riaz, S.; Hasan, S.; Syed, N.I. Synapse formation: From cellular and molecular mechanisms to neurodevelopmental and neurodegenerative disorders. J. Neurophysiol. 2019, 121, 1381-1397. [CrossRef]

81. Poggio, T. A Theory of How the Brain Might Work. Cold Spring Harb. Symp. Quant. Biol. 1990, 55, 899-910. [CrossRef] [PubMed]

82. Taverna, E.; Götz, M.; Huttner, W.B. The Cell Biology of Neurogenesis: Toward an Understanding of the Development and Evolution of the Neocortex. Annu. Rev. Cell Dev. Biol. 2014, 30, 465-502. [CrossRef] [PubMed]

83. Morrice, J.R.; Gregory-Evans, C.Y.; Shaw, C.A. Modeling Environmentally-Induced Motor Neuron Degeneration in Zebrafish. Sci. Rep. 2018, 8, 4890. [CrossRef] 
84. Wang, X.; Dong, Q.; Chen, Y.; Jiang, H.; Xiao, Q.; Wang, Y.; Li, W.; Bai, C.; Huang, C.; Yang, D. Bisphenol A affects axonal growth, musculature and motor behavior in developing zebrafish. Aquat. Toxicol. 2013, 142-143, 104-113. [CrossRef] [PubMed]

85. Welch, C.; Johnson, E.; Tupikova, A.; Anderson, J.; Tinsley, B.; Newman, J.; Widman, E.; Alfareh, A.; Davis, A.; Rodriguez, L.; et al Bisphenol A affects neurodevelopment gene expression, cognitive function, and neuromuscular synaptic morphology in Drosophila melanogaster. Neurotoxicology 2022, 89, 67-78. [CrossRef] [PubMed]

86. Liang, X.; Yin, N.; Liang, S.; Yang, R.; Liu, S.; Lu, Y.; Jiang, L.; Zhou, Q.; Jiang, G.; Faiola, F. Bisphenol A and several derivatives exert neural toxicity in human neuron-like cells by decreasing neurite length. Food Chem. Toxicol. 2020, 135, 111015. [CrossRef]

87. Xu, X.; Lu, Y.; Zhang, G.; Chen, L.; Tian, D.; Shen, X.; Yang, Y.; Dong, F. Bisphenol A promotes dendritic morphogenesis of hippocampal neurons through estrogen receptor-mediated ERK1/2 signal pathway. Chemosphere 2014, 96, 129-137. [CrossRef]

88. Xu, X.; Xie, L.; Hong, X.; Ruan, Q.; Lu, H.; Zhang, Q.; Zhang, G.; Liu, X. Perinatal exposure to bisphenol-A inhibits synaptogenesis and affects the synaptic morphological development in offspring male mice. Chemosphere 2013, 91, 1073-1081. [CrossRef]

89. Yin, Z.; Hua, L.; Chen, L.; Hu, D.; Li, J.; An, Z.; Tian, T.; Ning, H.; Ge, Y. Bisphenol-A exposure induced neurotoxicity and associated with synapse and cytoskeleton in Neuro-2a cells. Toxicol. Vitr. 2020, 67, 104911. [CrossRef]

90. Van Battum, E.Y.; Brignani, S.; Pasterkamp, R.J. Axon guidance proteins in neurological disorders. Lancet Neurol. 2015, 14, 532-546. [CrossRef]

91. McFadden, K.; Minshew, N.J. Evidence for dysregulation of axonal growth and guidance in the etiology of ASD. Front. Hum. Neurosci. 2013, 7, 671. [CrossRef] [PubMed]

92. Cruz, P.M.R.; Cossins, J.; Beeson, D.; Vincent, A. The Neuromuscular Junction in Health and Disease: Molecular Mechanisms Governing Synaptic Formation and Homeostasis. Front. Mol. Neurosci. 2020, 13, 610964. [CrossRef] [PubMed]

93. Zoghbi, H.Y.; Bear, M.F. Synaptic Dysfunction in Neurodevelopmental Disorders Associated with Autism and Intellectual Disabilities. Cold Spring Harb. Perspect. Biol. 2012, 4, a009886. [CrossRef]

94. Washbourne, P. Synapse Assembly and Neurodevelopmental Disorders. Neuropsychopharmacology 2014, 40, 4-15. [CrossRef] [PubMed]

95. Bourgeron, T. From the genetic architecture to synaptic plasticity in autism spectrum disorder. Nat. Rev. Neurosci. 2015, 16, 551-563. [CrossRef]

96. Stuchlik, A. Dynamic learning and memory, synaptic plasticity and neurogenesis: An update. Front. Behav. Neurosci. 2014, 8, 106. [CrossRef]

97. Davidson, R.J.; McEwen, B.S. Social influences on neuroplasticity: Stress and interventions to promote well-being. Nat. Neurosci. 2012, 15, 689-695. [CrossRef]

98. Segal, M. Dendritic spines: Morphological building blocks of memory. Neurobiol. Learn. Mem. 2017, 138, 3-9. [CrossRef]

99. Hasegawa, S.; Sakuragi, S.; Tominaga-Yoshino, K.; Ogura, A. Dendritic spine dynamics leading to spine elimination after repeated inductions of LTD. Sci. Rep. 2015, 5, 7707. [CrossRef]

100. Kawato, S.; Ogiue-Ikeda, M.; Soma, M.; Yoshino, H.; Kominami, T.; Saito, M.; Aou, S.; Hojo, Y. Perinatal Exposure of Bisphenol A Differently Affects Dendritic Spines of Male and Female Grown-Up Adult Hippocampal Neurons. Front. Neurosci. 2021, 15, 712261. [CrossRef]

101. Liu, Z.-H.; Ding, J.-J.; Yang, Q.-Q.; Song, H.-Z.; Chen, X.-T.; Xu, Y.; Xiao, G.; Wang, H.-L. Early developmental bisphenol-A exposure sex-independently impairs spatial memory by remodeling hippocampal dendritic architecture and synaptic transmission in rats. Sci. Rep. 2016, 6, 32492. [CrossRef] [PubMed]

102. Hu, F.; Zhang, L.; Li, T.; Wang, H.; Liang, W.; Zhou, Y. Bisphenol-A Exposure during Gestation and Lactation Causes Visual Perception Deficits in Rat Pups Following a Decrease in Interleukin $1 \beta$ Expression in the Primary Visual Cortex. Neuroscience 2020, 434, 148-160. [CrossRef] [PubMed]

103. Zhou, R.; Bai, Y.; Yang, R.; Zhu, Y.; Chi, X.; Li, L.; Chen, L.; Sokabe, M.; Chen, L. Abnormal synaptic plasticity in basolateral amygdala may account for hyperactivity and attention-deficit in male rat exposed perinatally to low-dose bisphenol-A Neuropharmacology 2011, 60, 789-798. [CrossRef] [PubMed]

104. Zhou, R.; Zhang, Z.; Zhu, Y.; Chen, L.; Sokabe, M. Deficits in development of synaptic plasticity in rat dorsal striatum following prenatal and neonatal exposure to low-dose bisphenol A. Neuroscience 2009, 159, 161-171. [CrossRef]

105. Wu, D.; Wu, F.; Lin, R.; Meng, Y.; Wei, W.; Sun, Q.; Jia, L. Impairment of learning and memory induced by perinatal exposure to BPA is associated with ER $\alpha$-mediated alterations of synaptic plasticity and PKC/ERK/CREB signaling pathway in offspring rats. Brain Res. Bull. 2020, 161, 43-54. [CrossRef]

106. Wang, C.; Niu, R.; Zhu, Y.; Han, H.; Luo, G.; Zhou, B.; Wang, J. Changes in memory and synaptic plasticity induced in male rats after maternal exposure to bisphenol A. Toxicology 2014, 322, 51-60. [CrossRef]

107. Elsworth, J.D.; Jentsch, J.D.; VandeVoort, C.A.; Roth, R.H., Jr. Prenatal exposure to bisphenol A impacts midbrain dopamine neurons and hippocampal spine synapses in non-human primates. Neuro Toxicol. 2013, 35, 113-120. [CrossRef]

108. Kimura, E.; Matsuyoshi, C.; Miyazaki, W.; Benner, S.; Hosokawa, M.; Yokoyama, K.; Kakeyama, M.; Tohyama, C. Prenatal exposure to bisphenol A impacts neuronal morphology in the hippocampal CA1 region in developing and aged mice. Arch. Toxicology 2016, 90, 691-700. [CrossRef]

109. Kumar, D.; Thakur, M. Anxiety like behavior due to perinatal exposure to Bisphenol-A is associated with decrease in excitatory to inhibitory synaptic density of male mouse brain. Toxicology 2017, 378, 107-113. [CrossRef] 
110. Xu, X.-H.; Zhang, J.; Wang, Y.-M.; Ye, Y.-P.; Luo, Q.-Q. Perinatal exposure to bisphenol-A impairs learning-memory by concomitant down-regulation of N-methyl-d-aspartate receptors of hippocampus in male offspring mice. Horm. Behav. 2010, 58, 326-333. [CrossRef]

111. Schneider, H.; Pitossi, F.; Balschun, D.; Wagner, A.; del Rey, A.; Besedovsky, H.O. A neuromodulatory role of interleukin-1 in the hippocampus. Proc. Natl. Acad. Sci. USA 1998, 95, 7778-7783. [CrossRef] [PubMed]

112. Eisinger, R.; Urdaneta, M.; Foote, K.; Okun, M.S.; Gunduz, A. Non-motor Characterization of the Basal Ganglia: Evidence From Human and Non-human Primate Electrophysiology. Front. Neurosci. 2018, 12, 385. [CrossRef] [PubMed]

113. Leranth, C.; Hajszan, T.; Szigeti-Buck, K.; Bober, J.; MacLusky, N. Bisphenol A prevents the synaptogenic response to estradiol in hippocampus and prefrontal cortex of ovariectomized nonhuman primates. Proc. Natl. Acad. Sci. USA 2008, 105, 14187-14191. [CrossRef] [PubMed]

114. Elsworth, J.D.; Jentsch, J.D.; Groman, S.M.; Roth, R.H., Jr.; Leranth, C. Low circulating levels of bisphenol-A induce cognitive deficits and loss of asymmetric spine synapses in dorsolateral prefrontal cortex and hippocampus of adult male monkeys. J. Comp. Neurol. 2015, 523, 1248-1257. [CrossRef] [PubMed]

115. Leranth, C.; Szigeti-Buck, K.; MacLusky, N.; Hajszan, T. Bisphenol A Prevents the Synaptogenic Response to Testosterone in the Brain of Adult Male Rats. Endocrinology 2007, 149, 988-994. [CrossRef]

116. Eilam-Stock, T.; Serrano, P.; Frankfurt, M.; Luine, V. Bisphenol-A impairs memory and reduces dendritic spine density in adult male rats. Behav. Neurosci. 2012, 126, 175-185. [CrossRef]

117. Inagaki, T.; Frankfurt, M.; Luine, V. Estrogen-Induced Memory Enhancements Are Blocked by Acute Bisphenol A in Adult Female Rats: Role of Dendritic Spines. Endocrinology 2012, 153, 3357-3367. [CrossRef]

118. Bowman, R.E.; Hagedorn, J.; Madden, E.; Frankfurt, M. Effects of adolescent Bisphenol-A exposure on memory and spine density in ovariectomized female rats: Adolescence vs. adulthood. Horm. Behav. 2019, 107, 26-34. [CrossRef]

119. Huarui, G.; Li, T.; Gong, H.; Chen, Z.; Jin, Y.; Xu, G.; Wang, M. Bisphenol A Impairs Synaptic Plasticity by Both Pre- and Postsynaptic Mechanisms. Adv. Sci. 2017, 4, 1600493. [CrossRef]

120. Lee, C.Y.; Hyun, S.-A.; Ko, M.Y.; Kim, H.R.; Rho, J.; Kim, K.K.; Kim, W.-Y.; Ka, M. Maternal Bisphenol A (BPA) Exposure Alters Cerebral Cortical Morphogenesis and Synaptic Function in Mice. Cereb. Cortex 2021, 31, 5598-5612. [CrossRef]

121. Aldridge, J.E.; Gibbons, J.A.; Flaherty, M.M.; Kreider, M.L.; Romano, J.A.; Levin, E.D. Heterogeneity of Toxicant Response: Sources of Human Variability. Toxicol. Sci. 2003, 76, 3-20. [CrossRef] [PubMed]

122. Musachio, E.A.S.; Couto, S.D.F.; Poetini, M.R.; Bortolotto, V.C.; Dahleh, M.M.M.; Janner, D.E.; Araujo, S.M.; Ramborger, B.P.; Rohers, R.; Guerra, G.P.; et al. Bisphenol A exposure during the embryonic period: Insights into dopamine relationship and behavioral disorders in Drosophila melanogaster. Food Chem. Toxicol. 2021, 157, 112526. [CrossRef] [PubMed]

123. Kaur, K.; Simon, A.; Chauhan, V.; Chauhan, A. Effect of bisphenol A on Drosophila melanogaster behavior-A new model for the studies on neurodevelopmental disorders. Behav. Brain Res. 2015, 284, 77-84. [CrossRef] [PubMed]

124. Olsvik, P.A.; Whatmore, P.; Penglase, S.J.; Skjærven, K.H.; D'Auriac, M.A.; Ellingsen, S. Associations Between Behavioral Effects of Bisphenol A and DNA Methylation in Zebrafish Embryos. Front. Genet. 2019, 10, 184. [CrossRef] [PubMed]

125. Saili, K.S.; Corvi, M.M.; Weber, D.N.; Patel, A.U.; Das, S.R.; Przybyla, J.; Anderson, K.A.; Tanguay, R.L. Neurodevelopmental low-dose bisphenol A exposure leads to early life-stage hyperactivity and learning deficits in adult zebrafish. Toxicology 2012, 291, 83-92. [CrossRef]

126. Anderson, O.S.; Peterson, K.E.; Sanchez, B.N.; Zhang, Z.; Mancuso, P.; Dolinoy, D.C. Perinatal bisphenol A exposure promotes hyperactivity, lean body composition, and hormonal responses across the murine life course. FASEB J. 2013, 27, 1784-1792 [CrossRef]

127. Plessen, K.J.; Bansal, R.; Zhu, H.; Whiteman, R.; Amat, J.; Quackenbush, G.A.; Martin, L.; Durkin, K.; Blair, C.; Royal, J.; et al. Hippocampus and Amygdala Morphology in Attention-Deficit/Hyperactivity Disorder. Arch. Gen. Psychiatry 2006, 63, 795-807. [CrossRef]

128. Zhou, N.; Yang, J.; Li, H.; Lu, Q.; Liu, Y.-D.; Lin, K.-F. Ecotoxicological evaluation of low-concentration bisphenol A exposure on the soil nematode Caenorhabditis elegansand intrinsic mechanisms of stress response in vivo. Environ. Toxicol. Chem. 2016, 35, 2041-2047. [CrossRef]

129. Jang, Y.J.; Park, H.R.; Kim, T.H.; Yang, W.-J.; Lee, J.-J.; Choi, S.Y.; Oh, S.B.; Lee, E.; Park, J.-H.; Kim, H.-P.; et al. High dose bisphenol A impairs hippocampal neurogenesis in female mice across generations. Toxicology 2012, 296, 73-82. [CrossRef]

130. Jašarević, E.; Williams, S.A.; Vandas, G.M.; Ellersieck, M.R.; Liao, C.; Kannan, K.; Roberts, R.M.; Geary, D.C.; Rosenfeld, C.S. Sex and dose-dependent effects of developmental exposure to bisphenol A on anxiety and spatial learning in deer mice (Peromyscus maniculatus bairdii) offspring. Horm. Behav. 2012, 63, 180-189. [CrossRef]

131. Johnson, S.A.; Javurek, A.B.; Painter, M.S.; Ellersieck, M.R.; Welsh, T.H.; Camacho, L.; Lewis, S.M.; Vanlandingham, M.M.; Ferguson, S.; Rosenfeld, C.S. Effects of developmental exposure to bisphenol A on spatial navigational learning and memory in rats: A CLARITY-BPA study. Horm. Behav. 2016, 80, 139-148. [CrossRef] [PubMed]

132. Xu, X.-B.; He, Y.; Song, C.; Ke, X.; Fan, S.-J.; Peng, W.-J.; Tan, R.; Kawata, M.; Matsuda, K.-I.; Pan, B.-X.; et al. Bisphenol a regulates the estrogen receptor alpha signaling in developing hippocampus of male rats through estrogen receptor. Hippocampus 2014, 24, 1570-1580. [CrossRef] [PubMed]

133. Poimenova, A.; Markaki, E.; Rahiotis, C.; Kitraki, E. Corticosterone-regulated actions in the rat brain are affected by perinatal exposure to low dose of bisphenol A. Neuroscience 2010, 167, 741-749. [CrossRef] [PubMed] 
134. Tian, Y.-H.; Baek, J.-H.; Lee, S.-Y.; Jang, C.-G. Prenatal and postnatal exposure to bisphenol a induces anxiolytic behaviors and cognitive deficits in mice. Synapse 2010, 64, 432-439. [CrossRef] [PubMed]

135. Wang, C.; Li, Z.; Han, H.; Luo, G.; Zhou, B.; Wang, S.; Wang, J. Impairment of object recognition memory by maternal bisphenol A exposure is associated with inhibition of Akt and ERK/CREB/BDNF pathway in the male offspring hippocampus. Toxicology 2016, 341-343, 56-64. [CrossRef]

136. Hass, U.; Christiansen, S.; Boberg, J.; Rasmussen, M.G.; Mandrup, K.; Axelstad, M. Low-dose effect of developmental bisphenol A exposure on sperm count and behaviour in rats. Andrology 2016, 4, 594-607. [CrossRef]

137. Matsuda, S.; Matsuzawa, D.; Ishii, D.; Tomizawa, H.; Sajiki, J.; Shimizu, E. Perinatal exposure to bisphenol A enhances contextual fear memory and affects the serotoninergic system in juvenile female mice. Horm. Behav. 2013, 63, 709-716. [CrossRef]

138. Nakamura, K.; Itoh, K.; Dai, H.; Han, L.; Wang, X.; Kato, S.; Sugimoto, T.; Fushiki, S. Prenatal and lactational exposure to low-doses of bisphenol A alters adult mice behavior. Brain Dev. 2012, 34, 57-63. [CrossRef]

139. Stump, D.G.; Beck, M.J.; Radovsky, A.; Garman, R.H.; Freshwater, L.L.; Sheets, L.P.; Marty, M.S.; Waechter, J.M.; Dimond, S.S.; Van Miller, J.P.; et al. Developmental Neurotoxicity Study of Dietary Bisphenol A in Sprague-Dawley Rats. Toxicol. Sci. 2010, 115, 167-182. [CrossRef]

140. Fujimoto, T.; Kubo, K.; Aou, S. Prenatal exposure to bisphenol A impairs sexual differentiation of exploratory behavior and increases depression-like behavior in rats. Brain Res. 2006, 1068, 49-55. [CrossRef]

141. Cox, K.H.; Gatewood, J.D.; Howeth, C.; Rissman, E.F. Gestational exposure to bisphenol A and cross-fostering affect behaviors in juvenile mice. Horm. Behav. 2010, 58, 754-761. [CrossRef] [PubMed]

142. Gao, R. Common Mechanisms of Excitatory and Inhibitory Imbalance in Schizophrenia and Autism Spectrum Disorders. Curr. Mol. Med. 2015, 15, 146-167. [CrossRef] [PubMed]

143. Selten, M.; Van Bokhoven, H.; Kasri, N.N. Inhibitory control of the excitatory/inhibitory balance in psychiatric disorders. F1000Research 2018, 7, 23. [CrossRef]

144. Mamiya, P.; Arnett, A.; Stein, M. Precision Medicine Care in ADHD: The Case for Neural Excitation and Inhibition. Brain Sci. 2021, 11, 91. [CrossRef] [PubMed]

145. Mhaouty-Kodja, S.; Belzunces, L.P.; Canivenc, M.-C.; Schroeder, H.; Chevrier, C.; Pasquier, E. Impairment of learning and memory performances induced by BPA: Evidences from the literature of a MoA mediated through an ED. Mol. Cell. Endocrinol. 2018, 475, 54-73. [CrossRef] [PubMed]

146. CLARITY-BPA Research Program. NTP Research Report on the Consortium Linking Academic and Regulatory Insights on Bisphenol A Toxicity (CLARITY-BPA): A Compendium of Published Findings: Research Report 18. 2021. Available online: https: / / pubmed.ncbi.nlm.nih.gov/34910417/ (accessed on 4 March 2022).

147. Rebolledo-Solleiro, D.; Flores, L.Y.C.; Solleiro-Villavicencio, H. Impact of BPA on behavior, neurodevelopment and neurodegeneration Daniela. Front. Biosci. 2021, 26, 363-400. [CrossRef]

148. Bakoyiannis, I.; Kitraki, E.; Stamatakis, A. Endocrine-disrupting chemicals and behaviour: A high risk to take? Best Pr. Res. Clin. Endocrinol. Metab. 2021, 35, 101517. [CrossRef]

149. Nesan, D.; Kurrasch, D.M. Gestational Exposure to Common Endocrine Disrupting Chemicals and Their Impact on Neurodevelopment and Behavior. Annu. Rev. Physiol. 2020, 82, 177-202. [CrossRef]

150. Xin, F.; Fischer, E.; Krapp, C.; Krizman, E.N.; Lan, Y.; Mesaros, C.; Snyder, N.W.; Bansal, A.; Robinson, M.B.; Simmons, R.A.; et al. Mice exposed to bisphenol A exhibit depressive-like behavior with neurotransmitter and neuroactive steroid dysfunction. Horm. Behav. 2018, 102, 93-104. [CrossRef]

151. Santoro, A.; Chianese, R.; Troisi, J.; Richards, S.; Nori, S.L.; Fasano, S.; Guida, M.; Plunk, E.; Viggiano, A.; Pierantoni, R.; et al. Neuro-toxic and Reproductive Effects of BPA. Curr. Neuropharmacol. 2019, 17, 1109-1132. [CrossRef] 